\title{
Comparison of CMIP6 and CMIP5 models in simulating mean and extreme precipitation over East Africa.
}

\author{
Brian Ayugi ${ }^{1,2}$, Jiang Zhihong ${ }^{2 *}$, Huanhuan Zhu $^{2}$, Hamida Ngoma ${ }^{2,3}$, Hassen Babaousmail ${ }^{4}$, \\ Karim Rizwan ${ }^{2}$, Victor Dike $e^{5,6}$ \\ ${ }^{1}$ Jiangsu Key Laboratory of Atmospheric Environment Monitoring and Pollution Control, Collab \\ orative Innovation Center of Atmospheric Environment and Equipment Technology, School of En \\ vironmental Science and Engineering, Nanjing University of Information Science and Technolog \\ y, Nanjing 210044, China
}

${ }^{2}$ Key Laboratory of Meteorological Disaster, Ministry of Education (KLME)/Joint International Research Laboratory of Climate and Environment Change (ILCEC)/Collaborative Innovation Center on Forecast and Evaluation of Meteorological Disasters (CIC-FEMD), Nanjing, University of Information Science and Technology, Nanjing 210044, China
${ }^{3}$ Makerere University, Department of Geography, Geoinformatics and Climatic Sciences, P.O. Box 7062 Kampala Uganda

${ }^{4}$ Binjiang College of Nanjing University of Information Science and Technology, Jiangsu, Wuxi, China

${ }^{5}$ International Center for Climate and Environment Sciences, Institute of Atmospheric Physics, Chinese Academy of Sciences, Beijing 100029, China

${ }^{6}$ Energy, Climate, and Environment Science Group, Imo State Polytechnic Umuagwo, Ohaji, PMB 1472 Owerri, Imo State, Nigeria

*Corresponding author: zhjiang@ nuist.edu.cn 


\begin{abstract}
This study examines the improvement in coupled intercomparison project phase six (CMIP6) models against the predecessor CMIP5 in simulating mean and extreme precipitation over the East Africa region. The study compares the climatology of the precipitation indices simulated by the CMIP models with the CHIRPS dataset using robust statistical techniques for $1981-2005$. The results display the varying performance of the general circulation models (GCMs) in the simulation of annual and seasonal precipitation climatology over the study domain. CMIP6-MME shows improved performance in the local annual mean cycle simulation with a better representation of two peaks, especially the MAM rainfall relative to its predecessor. Moreover, simulation of extreme indices is well captured in CMIP6 models relative to its predecessor. The CMIP6-MME performed better than the CMIP5-MME with lesser biases in simulating SDII, CDD, and R20mm over East Africa. Remarkably, most CMIP6 models are unable to simulate extremely wet days (R95p). A few CMIP6 models (e.g., NorESM2-MM and CNRM-CM6-1) depicts robust performance in reproducing the observed indices across all analyses. Conversely, OND season shows the overestimation of some indices (i.e., R95p, PRCPTOT), except for SDII, CDD, and R20mm. Consistent with other studies, the mean ensemble performance for both CMIP5/6 shows better performance due to the cancellation of some systematic errors in the individual models. Generally, the CMIP6 depicts improved performance in the simulation of MAM season akin CMIP5 models. However, the new model generation is still marred with uncertainty, thereby depicting substandard performance over the East Africa domain. This calls for further investigation of attribution studies into the sources of persistent systematic biases and a prerequisite for identifying individual models with robust features that can accurately simulate observed patterns for future usage.
\end{abstract}

Key words: CMIP5/6, Precipitation, Climate extremes, evaluation, East Africa

\title{
1. Introduction
}

The twenty-first century has witnessed unprecedented occurrences of extreme events that adversely affect every component of societal infrastructure and natural ecosystems (IPCC, 2018). Nations in the extratropics continue to bear the brunt of climate change, characterized by incidences such as acute drought and floods, wildfires, tropical cyclones, and heatwaves, etc. 
(IPCC, 2014, 2018). Regions that were predominately considered 'safe havens' have been hit by far-reaching impacts of anomalous events, thereby weakening their economy and resilience to cope with the situations (Dahinden et al., 2017; Madakumbura et al., 2019). If such patterns are not accurately and timely forecasted and projected of how they will evolve in future trends, the catastrophic impact leading to massive loss of human lives and property will be the 'new norm'. This calls for all relevant stakeholders'actions to devise possible measures and solutions to minimize any potential damages.

The scientific community continue to play a critical role in providing timely and accurate information regarding the evolution of climate extremes that currently define the present world and the future incidences. The advent of Coupled Model Intercomparison Project (CMIP https://www.wcrp-climate.org/wgcm-cmip) has significantly aided in understanding the projected patterns of the climate system. Resultant advancement is the General Circulation Models (GCMs), capable of enhancing our understanding of the climate system. The output of these models informs relevant stakeholders on formulation of effective and sustainable policies.

The steady progress from the first experiments conducted in a bid to enhance our knowledge of the complex earth system to the latest sixth phase (CMIP6) has witnessed remarkable improvement. Consequently, numerous studies have been conducted across various spectrums using the GCMs in an attempt to understand, attribute, and/or simulate various aspects of climate systems. Nevertheless, glaring weakness have been noted in various outputs of CMIP datasets over different regions. For instance, the first two phases of CMIP entailed simple simulations involving $\mathrm{CO}_{2}$ concentration which was subjected to an increase at a rate of $1 \%$ yearly thereby no interannual variations in the radiative forcing being permitted (Meehl et al.,1997; 2005; Stouffer et al., 2016). First forward, notable advances in the modelling of climate systems have been witnessed with the development of the fifth phase of the CMIP(CMIP5) comparable to the predecessors (Taylor et al., 2012; Smith et al., 2013). To illustrate, the CMIP5 entailed more model outputs than CMIP3 and involve use of Representative Concentration Pathways (RCPs; Riahi et al., 2007; van Vuuren et al., 2007). Other significant features can be accessed from relavant literature (Lamarque et al., 2013; Eyring et al., 2013; Taylor et al., 2012; Friedlingstein et al., 2014).

Despite the significant progress and new developments in phase 5, significant impediments still remained unresolved. For instance, the quantification of radiative forcing and responses 
continued to depict unsatisfactory performance (Stouffer et al., 2016). Further, the CMIP5 outputs are still marred with persistent systematic model biases, leading to major climate uncertainties (Flato et al., 2013). Other challenges noted involve the aspect of inadequate comprehension of the mechanism influencing internal changes, hence, unskillful decadal climate predictions (Meehl et al., 2007, 2009; Collins et al., 2013). This resulted in more experiments that would attempt to address some of these pertinent issues that were noticeable in the model outputs used for the generation of IPCC assessment report 5 (AR5 report).

As a way forward, CMIP6, has been developed with massive improvements included as compared to previous outputs (Eyring et al., 2016). To illustrate this, higher spatial resolution ( $70 \mathrm{~km}$ ) in comparison to coarser resolution $(\sim 250 \mathrm{~km})$ for CMIP5 characterizes the current model generation. Besides, improved physical processes and biogeochemical cycles, new features such as improved aerosols' effect or refined parameterization schemes, and large ensemble members are among the developments that describe the latest model outputs. Subsequently, large volumes of research outputs based on CMIP6 have highlighted notable improvements in modelling various aspects of climate systems or comparative analysis of the added value in CMIP6 as compared to CMIP5 (Voldoire et al., 2019; Mauritsen et al., 2019; Hajima et al., 2020; Moseid et al., 2020).

Studies focusing on simulations or projection of mean and extreme climate based on CMIP6 (e.g., Akinsanola et al., 2020; Almazroui et al., 2020a, b; Grose et al., 2020; Jiang et al., 2020) or comparative studies of CMIP6 against CMIP5 performance have also reported better and more reliable results (Gusain et al., 2020; Jiang et al., 2020; Luo et al., 2020; Nie et al., 2020; Senevirante and Hauser, 2020; Zamani et al., 2020; Zhu et al., 2020). Chen et al. (2020), while equating the performance of CMIP6 to CMIP5 in the simulation of climate extreme noted a significant reduction in the model spread among the CMIP6 models compared to CMIP5, particularly over regions in the northern latitudes. Mainly, the study observed a more distinct projections of precipitation indices depicting very heavy precipitation days above $20 \mathrm{~mm}$ (R20mm) and maximum consecutive 5-day precipitation (RX5day) than in CMIP5 simulations.

Conversely, a regional study conducted using CMIP6 across the 41 sub-regions globally, as delineated for the upcoming IPCC assessment report six (AR6) reveals limited improvements compared to the CMIP5 models (Kim et al., 2020). Interestingly, the study shows persistent systematic biases (i.e., cold biases) in cold extremes over high-latitude regions. Nonetheless, simulation of precipitation extreme depicts an improved model skill in CMIP6 for the indices 
denoting the intensity and frequency with evidently reduced biases. The aforementioned studies continue to show varying results in the simulations of mean or extreme climate events in CMIP6 as compared to the predecessor. Remarkably, these studies continue to enhance our understanding of the suitable models to be employed for accurate diagnosis and projection of impact analysis.

Over East Africa (Figure. 1), the livelihood of a population that is mainly dependent on precipitation is under threat posed by pronounced extreme events (Shongwe et al., 2011; Senevirante et al., 2012; Niang et al., 2014; Ongoma et al., 2018a; Gebrechorkos etal., 2019). The damages witnessed over the recent years is threatening the economy and ecosystem wellbeing (IPCC, 2014). Extreme droughts (Nicholson, 2014; Haile et al., 2019; Tan et al., 2020) and floods (Kilavi et al., 2018; Juma et al., 2020) remain the signature features affecting millions of people and has a negative impact on the gross domestic product in the region that is mainly dependent on rainfed agriculture (World Bank, 2012; FAO, 2019). Characterizing observed events have been based on various reanalysis or satellite-derived datasets with clear patterns observed and hotspots identified (Liebman et al., 2014; Lyon, 2014; Gebremeskel et al., 2019). However, future projection studies of mean and extremes climate have been conducted using the available GCMs from CMIP3/5 (Shongwe et al., 2011; Otieno and Anyah, 2013a, b; Ongoma et al., 2018a, 2018b) or dynamically downscaled regional datasets (RCMs) (Osima et al., 2018; Ayugi et al., 2020; Onyutha, 2020; Ogega et al., 2020).

As witnessed across other regions, the discrepancies in CMIP5 or RCMs are equally recognized in studies that have been based on such datasets over EA domain (Rowell et al., 2015; Yang et al., 2015; Kent et al., 2015; Kisembe et al., 2018; Ongoma et al., 2018a). Remarkably, no studies so far that have employed the latest CMIP6 model outputs to examine their capability in simulating the observed extreme events nor projecting the possible future incidences over the region. The improved performances illustrated over various domain gives a promise of accurate and reliable projections of future climate in a region that have been referred to demonstrate "paradox" pattern based on previous versions (Rowell et al., 2015).

Thus, this study seeks to establish whether the CMIP6 models have stronger capability to reproduce mean seasonal and extreme events over EA region and whether the uncertainty is narrowed in CMIP6 as compared to CMIP5? The rest of the paper is organized as follows: details of data and techniques employed are enumerated in section 2 while results are captured in section 
3. Discusions are presented in section 4. Lastly, the conclusion and recommendation are highlighted in part 5.

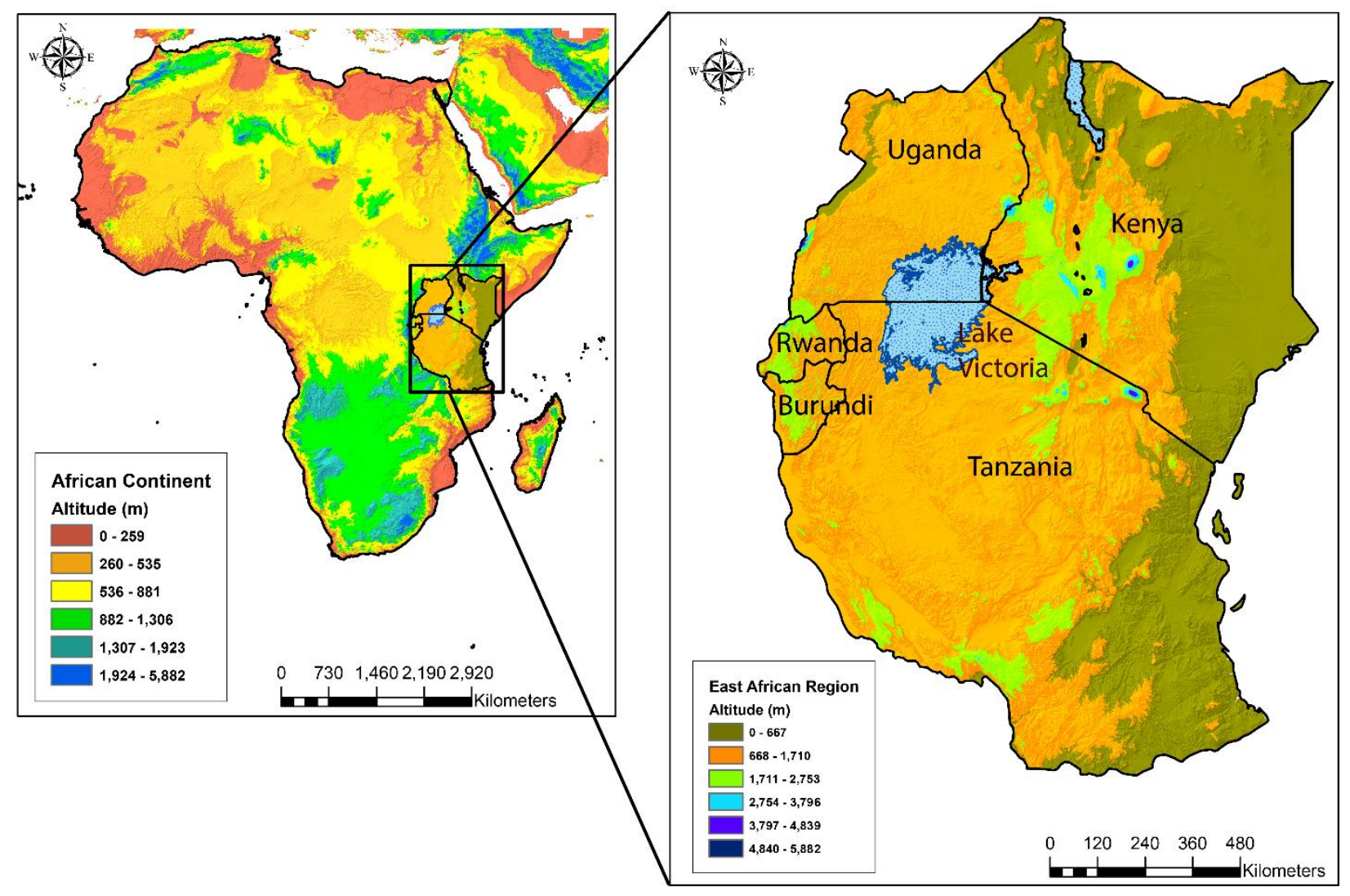

Figure 1. The map of Africa delineating different sub-regions. The east Africa region marked as with countries considered for analysis in this study.

\section{Data and methods}

\subsection{Model outputs and observation}

This study uses thirteen historical simulations of CMIP6 (Eyring et al., 2016) and the predecessor (Taylor et al., 2012) obtained from an open-source platform available at https://esgfnode.llnl.gov/projects/esgf-1lnl. The details regarding the dataset's structures are well presented in Table 1. A summary table highlighting the notable advances in the CMIP6 as equated to the precursor version is presented in Table 2. To enable intercomparison, only first member realization outputs (r1ilp1f1) for CMIP6 and r1ilp1 for CMIP5 are utilized in this study, despite the large ensemble members available in CMIP6 datasets.

The Climate Hazard Group InfraRed Precipitation with Station data (CHIRPS version 2) is employed as observed data owing to its superior performance over the study region as compared 
to other existing datasets (Kimani et al., 2017, Cattani et al., 2018; Gebrechorkos et al., 2018; Dinku et al., 2018; Ayugi et al., 2019). More details regarding the algorithm and production process can be accessed from Funk et al. (2015). Many studies have pointed out insuffiecient reliable in-situ datasets that can be used for weather and climate studies over the EA region (Camberlin and Okoola, 2003; Su et al., 2008). The advent of alternative sources such as satellitederived or reanalysis datasets has played a critical role as a substitute source for climate estimates. In this paper, all datasets are aggregated to a uniform temporal scale of 1981 - 2005 and lowest spatial resolution of model using robust remapping technique. 
Table 1. Model names, modeling centers and countries, as well as the atmospheric resolutions, of 13 CMIP6 global climate models and their CMIP5 predecessors.

\begin{tabular}{llc}
\hline \multicolumn{1}{c}{ Model name } & \multicolumn{1}{c}{ Modeling center and country } & $\begin{array}{c}\text { Atmospheric } \\
\text { resolution (lat } \times \text { lon) }\end{array}$ \\
\hline ACCESS-ESM1-5 & Commonwealth Scientific and Industrial Research & $1.25^{\circ} \times 1.875^{\circ}$ \\
ACCESS1.0 & Organization and Bureau of Meteorology (Australia) & $1.25^{\circ} \times 1.875^{\circ}$ \\
BCC-CSM2-MR & Beijing Climate Center, China Meteorological & $1.125^{\circ} \times 1.125^{\circ}$ \\
bcc-csm1.1-m & Administration (China) & $1.125^{\circ} \times 1.125^{\circ}$ \\
CanESM5 & Canadian Centre for Climate Modelling and Analysis & $2.8^{\circ} \times 2.8^{\circ}$ \\
CanESM2 & (Canada) & $2.8^{\circ} \times 2.8^{\circ}$ \\
CNRM-CM6-1 & Centre National de Recherches Météorologiques- & $1.4^{\circ} \times 1.4^{\circ}$ \\
CNRM-CM5 & Centre Européen de Recherche et de Formation & $1.4^{\circ} \times 1.4^{\circ}$ \\
FGOALS-g3 & Avancée en Calcul Scientifique (France) & $2.25^{\circ} \times 2^{\circ}$ \\
FGOALS-g2 & LASG, Institute of Atmospheric Physics, Chinese & $30^{\circ} \times 2.8^{\circ}$ \\
INM-CM4-8 & Academy of Sciences and Center for Earth System & $1.5^{\circ} \times 2^{\circ}$ \\
INM-CM4 & Institute for Numerical Mathematics, Russian & $1.5^{\circ} \times 2^{\circ}$ \\
IPSL-CM6A-LR & Academy of Science /Russia & $1.26^{\circ} \times 2.5^{\circ}$ \\
IPSL-CM5A-LR & L'Institut Pierre-Simon Laplace (France) & $1.875^{\circ} \times 3.75^{\circ}$ \\
MIROC6 & & $1.4^{\circ} \times 1.4^{\circ}$ \\
MIROC5 & National Institute for Environmental Studies, & $1.4^{\circ} \times 1.4^{\circ}$ \\
MIROC-ES2L & The University of Tokyo (Japan) & $2.8^{\circ} \times 2.8^{\circ}$ \\
MIROC-ESM & & $2.8^{\circ} \times 2.8^{\circ}$ \\
MPI-ESM-1-2-HR & & $0.94^{\circ} \times 0.94^{\circ}$ \\
MPI-ESM-MR & Max Planck Institute for Meteorology (Germany) & $1.875^{\circ} \times 1.875^{\circ}$ \\
MPI-ESM-1-2-LR & & $1.875^{\circ} \times 1.875^{\circ}$ \\
MPI-ESM-LR & & $1.875^{\circ} \times 1.875^{\circ}$ \\
MRI-ESM2-0 & Meteorological Research Institute (Japan) & $1.125^{\circ} \times 1.125^{\circ}$ \\
MRI-CGCM3 & & $1.125^{\circ} \times 1.125^{\circ}$ \\
NorESM2-MM & Norwegian Climate Centre (Norway) & $0.94^{\circ} \times 1.25^{\circ}$ \\
NorESM1-M & & $1.88^{\circ} \times 2.5^{\circ}$ \\
\hline Note: The models from CMIP6 are in bold. & \\
\hline
\end{tabular}

Note: The models from CMIP6 are in bold. 
Table 2. Simple introduction of the updates of CMIP6 models compared with that in CMIP5

\begin{tabular}{|c|c|c|c|c|}
\hline Models & Institute, Country & $\begin{array}{l}\text { Atmospheric } \\
\text { resolution }\end{array}$ & Major improvements & References \\
\hline $\begin{array}{l}\text { ACCESS- } \\
\text { ESM1-5/ } \\
\text { ACCESS1.0 }\end{array}$ & $\begin{array}{l}\text { Commonwealth } \\
\text { Scientific and } \\
\text { Industrial Research } \\
\text { Organization and } \\
\text { Bureau of } \\
\text { Meteorology } \\
\text { (Australia) } \\
\end{array}$ & $\begin{array}{l}1.25^{\circ} \times 1.875^{\circ} \\
1.25^{\circ} \times 1.875^{\circ}\end{array}$ & $\begin{array}{l}\text { The improvement in the bio-geochemical } \\
\text { components for the land and ocean to } \\
\text { simulate the global carbon cycle. The } \\
\text { Model is also the only CMIP6 model with } \\
\text { phosphorous limitations on the land, } \\
\text { highlighting its unique status. }\end{array}$ & Ziehn et al., 2019 \\
\hline $\begin{array}{l}\text { BCC-CSM2- } \\
\text { MR/ } \\
\text { BCC-CSM1.1- } \\
\text { M }\end{array}$ & $\begin{array}{l}\text { Beijing Climate } \\
\text { Center (BCC), China }\end{array}$ & $\begin{array}{l}\text { T42, L26/ } \\
\text { T106, T46 }\end{array}$ & $\begin{array}{l}\text { Modification of the deep convection } \\
\text { parameterization, a mew scheme for the } \\
\text { cloud fraction and indirect effects of } \\
\text { aerosols; Significant improvement in } \\
\text { surface processes of BCC-AVIM; new } \\
\text { schemes for surface turbulent fluxes of } \\
\text { momentum, heat, and water }\end{array}$ & Wu et al., 2019 \\
\hline $\begin{array}{l}\text { CanESM5/ } \\
\text { CanESM2 }\end{array}$ & $\begin{array}{l}\text { Canadian Climate } \\
\text { Centre, Canada }\end{array}$ & $\begin{array}{l}\text { T63, L49/ T63, } \\
\text { L49 }\end{array}$ & $\begin{array}{l}\text { Completely new models for the ocean, sea } \\
\text { ice, and marine ecosystems, and a new } \\
\text { coupler }\end{array}$ & Swart et al., 2019 \\
\hline $\begin{array}{l}\text { CNRM-CM6- } \\
\text { 1/ } \\
\text { CNRM-CM5 }\end{array}$ & $\begin{array}{l}\text { Centre National de } \\
\text { Recherches } \\
\text { Météorologiques } \\
\text { (CNRM) and } \\
\text { Cerfacs }\end{array}$ & $1.4^{\circ} / \mathrm{T} 1127$ & $\begin{array}{l}\text { Improvement in the mass and energy } \\
\text { conservation in the simulated climate } \\
\text { system to limit long-tern drift. Also, deep } \\
\text { ocean biases are generally reduced, whereas } \\
\text { sea ice in the Artic improved. Sensitivity in } \\
\text { rising } \mathrm{CO}_{2} \text { in the model has increased. } \\
\text { Lastly is the equilibrium climate sensitivity } \\
(4.9 \mathrm{~K}) \text { is now close to the upper bound of } \\
\text { the range estimated from CMIP5 models. }\end{array}$ & $\begin{array}{l}\text { Voldoire et al., } \\
2019\end{array}$ \\
\hline $\begin{array}{l}\text { FGOALS-g3/ } \\
\text { FGOALS-g2 }\end{array}$ & $\begin{array}{l}\text { Institute of } \\
\text { Atmospheric Physics } \\
\text { (IAP), Chinese } \\
\text { Academy of Sciences } \\
\text { (CAS), China }\end{array}$ & $\begin{array}{l}2.8^{\circ} \times 3.1^{\circ}, \mathrm{L} 26 / \\
2.0^{\circ}, \mathrm{L} 26\end{array}$ & $\begin{array}{l}\text { Improved TSPAS advection; new schemes } \\
\text { for the physical process, including the } \\
\text { boundary layer, stratiform cloud; A } \\
\text { convection momentum transport has been } \\
\text { considered }\end{array}$ & Li et al., 2020 \\
\hline $\begin{array}{l}\text { INM-CM4-8/ } \\
\text { INM-CM4 }\end{array}$ & $\begin{array}{l}\text { Institute of numerical } \\
\text { mathematics (INM) } \\
\text { of the Russian } \\
\text { Academy of } \\
\text { Sciences, Russia }\end{array}$ & $\begin{array}{l}2^{\circ} \times 1.5^{\circ}, \quad \text { L21/ } \\
2^{\circ} \times 1.5^{\circ}, \text { L73 }\end{array}$ & $\begin{array}{l}\text { A more sophisticated parameterization of } \\
\text { condensation and cloudiness formation; } \\
\text { incorporating an aerosol module; upgraded } \\
\text { oceanic component }\end{array}$ & $\begin{array}{l}\text { Volodin et al., } \\
2017\end{array}$ \\
\hline $\begin{array}{l}\text { IPSL-CM6A- } \\
\text { LR/ } \\
\text { IPSL-CM5A- } \\
\text { LR }\end{array}$ & $\begin{array}{l}\text { Institute Pierre } \\
\text { Simon Laplace } \\
\text { (IPSL), France }\end{array}$ & $\begin{array}{l}3.75^{\circ} \times 1.9^{\circ}, \text { L39 } \\
/ 2.5^{\circ} \times 1.3^{\circ}, \text { L79 }\end{array}$ & $\begin{array}{l}\text { Including new versions of LMDZ, of } \\
\text { NEMO and of ORCHIDEE; improved } \\
\text { conservation of energy and water; increased } \\
\text { resolutions for atmosphere and land- } \\
\text { surface, and for ocean }\end{array}$ & $\begin{array}{l}\text { Hourdin et al., } \\
2019\end{array}$ \\
\hline $\begin{array}{l}\text { MIROC6/ } \\
\text { MIROC5 }\end{array}$ & $\begin{array}{l}\text { The center for } \\
\text { climate system } \\
\text { research, the } \\
\text { university of Tokyo, } \\
\text { the Japan Agency for } \\
\text { Marine-Earth } \\
\text { Science and } \\
\text { Technology, and the } \\
\text { national institute for } \\
\text { environmental } \\
\text { studies, Japan }\end{array}$ & $\begin{array}{l}\text { T85, L40/ T85, } \\
\text { L81 }\end{array}$ & $\begin{array}{l}\text { Incorporating a new parameterization for } \\
\text { shallow convective processes; an updated } \\
\text { k-distribution scheme for radiative transfer; } \\
\text { a new parameterization for non-orographic } \\
\text { gravity wave }\end{array}$ & Tatebe et al., 2019 \\
\hline $\begin{array}{l}\text { MIROC- } \\
\text { ES2L/ } \\
\text { MIROC-ESM }\end{array}$ & $\begin{array}{l}\text { National Institute for } \\
\text { Environmental } \\
\text { Studies, The } \\
\text { University of Tokyo } \\
\text { (Japan) }\end{array}$ & $\begin{array}{ll}\text { T42; } & \text { L128, } \\
\text { 64/L40 } & \end{array}$ & $\begin{array}{l}\text { The model's ocean biogeochemical } \\
\text { component has been largely been updated } \\
\text { to simulate the biogeochemical cycles of } \\
\text { carbon, nitrogen, phosphorus, iron, and } \\
\text { oxygen such that primary productivity can } \\
\text { be controlled by multiple nutrient } \\
\text { limitations. }\end{array}$ & $\begin{array}{l}\text { Hamija et al., } \\
2020\end{array}$ \\
\hline MPI-ESM1-2- & Max Planck Institute & $\mathrm{T} 63 / \mathrm{T} 127$ & New radiation & Mauritsen et al. \\
\hline
\end{tabular}




\begin{tabular}{|c|c|c|c|c|}
\hline $\begin{array}{l}\mathbf{H R} / \\
\text { MPI-ESM-LR }\end{array}$ & (MPI), Germany & & $\begin{array}{l}\text { parameterizations; introducing a multilayer } \\
\text { soil hydrology scheme, extending the land } \\
\text { biogeochemistry to include the nitrogen } \\
\text { cycle; the ocean biogeochemistry now } \\
\text { represents cyanobacteria prognostically }\end{array}$ & 2019 \\
\hline $\begin{array}{l}\text { MPI-ESM-1- } \\
\text { 2-LR/ } \\
\text { MPI-ESM-LR }\end{array}$ & $\begin{array}{l}\text { Max Planck Institute } \\
\text { (MPI), Germany }\end{array}$ & $\begin{array}{l}\text { T63; } \\
\text { L192,96/L47 }\end{array}$ & $\begin{array}{l}\text { The new radiation and aerosol } \\
\text { parameterization of the atmosphere, several } \\
\text { relatively large, but partly compensating, } \\
\text { coding errors in the model's cloud, } \\
\text { convection, turbulence parameterizations } \\
\text { have been improved. The representation of } \\
\text { land processes has been refined by } \\
\text { introducing a multilayer soil and litter } \\
\text { decomposition model and improving the } \\
\text { representation of wildfires. }\end{array}$ & $\begin{array}{l}\text { Mauritsen et al., } \\
2019\end{array}$ \\
\hline $\begin{array}{l}\text { MRI-ESM2-0/ } \\
\text { MRI-CGCM3 }\end{array}$ & $\begin{array}{l}\text { Meteorological } \\
\text { Research Institute } \\
\text { (MRI), Japan }\end{array}$ & $\begin{array}{l}\text { TL159, L48/ } \\
\text { TL159, L80 }\end{array}$ & $\begin{array}{l}\text { New stratocumulus parameterization; the } \\
\text { new stratocumulus scheme; new treatment } \\
\text { of the WBF effect }\end{array}$ & $\begin{array}{l}\text { Yukimoto et al., } \\
2019\end{array}$ \\
\hline $\begin{array}{l}\text { NorESM2- } \\
\text { MM } \\
\text { NorESM1-M/ }\end{array}$ & $\begin{array}{ll}\text { Norwegian } & \text { Climate } \\
\text { Centre } & \text { (NCC), } \\
\text { Norway } & \end{array}$ & $\begin{array}{l}1.9^{\circ} \times 2.5^{\circ}, \quad \text { L26 } \\
/ 1.9^{\circ} \times 2.5^{\circ}, \text { L32 }\end{array}$ & $\begin{array}{l}\text { Improved energy and angular momentum } \\
\text { conservation; improved deep convection; } \\
\text { improved aerosol handling; new sea-salt } \\
\text { emission parameterization; online } \\
\text { emissions of mineral dust; improved } \\
\text { heterogeneous ice nucleation treatment }\end{array}$ & Seland et al., 2020 \\
\hline
\end{tabular}

Note: The models from CMIP6 are in bold.

\subsection{Climate indices}

This study employs extreme climate indices distinct by the Expert Team on Climate Change Detection and Monitoring Indices (ETCCDMI). The listed indices mainly considered aspects of extreme intensity, frequency, and duration of precipitation events over the study area (Klein Tank et al., 2009; Zhang et al., 2011). The indices can be divided into four main classes. Firstly, the duration indices, which mainly defines periods of excessive wetness/dryness. Here we used consecutive dry days (CDD) that represent the extent of the most prolonged dry anomaly in a year, characterizing the possible drought occurrence. Secondy, a percentile-based index that defines very wet days (R95P). The precipitation index used in this classification represents the rainfall amount falling about the $95^{\text {th }}$ (R95p). The threshold-based indices, identified as count of days when precipitation quantity is above/below a fixed threshold is equally employed. Here, we defined the sum of very heavy precipitation days > $20 \mathrm{~mm}$ (R20). Lastly, the study employed indices that delineate the period of seasonal precipitation total (PRCPTOT) and those that define precipitation intensity, such as the simple daily intensity index (SDII). Details regarding the indices are providedin Table 3 . 
Table 3. Definitions and units of precipitation Indices employed in this study

\begin{tabular}{|c|c|c|c|}
\hline ID & Name & Definitions & Units \\
\hline PRCPTOT & $\begin{array}{l}\text { Wet-day precipitation } \\
\text { amount }\end{array}$ & $\begin{array}{l}\text { Total precipitation in wet days }(\mathrm{RR} \geq 1 \\
\mathrm{mm}) \text {, defined as } P P_{i j} \text { representing daily } \\
\text { precipitation amount on day } \mathrm{I} \text { in a period } \mathrm{j} \text {. } \\
\text { If the I denote the number of days in } \mathrm{j} \text {, then; } \\
P R C P T O T_{j}=\sum_{i=1}^{i} P P_{i j}\end{array}$ & $\mathrm{~mm}$ \\
\hline R95p & Extremely wet days & $\begin{array}{l}\text { Total precipitation when } \mathrm{PP}>95 \text { th } \\
\text { percentile. Here, } P P_{c d} \text { be daily precipitation } \\
\text { amount on a wet day } c(\mathrm{PP} \geq 1.0 \mathrm{~mm}) \text { in a } \\
\text { period } i \text { and let } P P_{c d^{95} \text {. where } 95^{\text {th }}} \\
\text { percentile of precipitation on wet days in the } \\
\text { baseline/projected period. If d represent the } \\
\text { number of wet days in the period, then } \\
R 95 P_{j}=\sum_{c=1}^{c} P P_{c d} \text { where } P P_{c d}>P P_{c d^{95}}\end{array}$ & $\mathrm{~mm}$ \\
\hline SDII & Wet-day intensity & $\begin{array}{l}\text { Average precipitation from wet-days. This } \\
\text { can be defined as } P P_{w j} \text { be the daily } \\
\text { precipitation amount on wet days, } w(\mathrm{PP} \geq 1 \\
\text { mm) in period } \mathrm{j} \text {. If } w \text { represents number of } \\
\text { wet days in } \mathrm{j} \text {, then } S D I I_{j}=\frac{\sum_{w=1}^{w} P P_{w j}}{W}\end{array}$ & $\mathrm{~mm} /$ day \\
\hline $\mathrm{R} 20 \mathrm{~mm}$ & $\begin{array}{l}\text { Heavy precipitation } \\
\text { days }\end{array}$ & $\begin{array}{l}\text { Number of very heavy precipitation days } \\
(\mathrm{RR} \geq 20 \mathrm{~mm}) \text {. That is; let } P P_{i j} \text { be the daily } \\
\text { precipitation amount where } P P_{i j} \geq 20 \mathrm{~mm}\end{array}$ & days \\
\hline CDD & Consecutive dry days & $\begin{array}{l}\text { Maximum number of consecutive dry days } \\
(\mathrm{RR} \leq 1 \mathrm{~mm}) \text {. Let } P P_{i j} \text { be the daily } \\
\text { precipitation amount on day } \mathrm{I} \text { in period } \mathrm{j} \text {. } \\
\text { Count the largest consecutive days where } \\
P P_{i j} \leq 1 \mathrm{~mm}\end{array}$ & days \\
\hline
\end{tabular}

\subsection{Evaluation techniques}

Various multi-model statistics such as spatial coefficient correlation (SCC), spatial standard deviation (SSD), and spatial variation of root mean square error (RMSE) are used to assess the overall skills of models simulating the observed extreme events during two main rainy seasons (i.e., March to May[MAM] and October to December [OND]) over the study area. The widely used metrics are summarized using Taylor diagram (TD; Taylor, 2001). The value of SCC close to 1 denotes perfect positive model performance while -1 shows the inability of models to reflect the observed features. Conversely, the perfect representation of RMSE is depicted by 0 and that of SSD is 1. Recent approach of model ranking, also known as Taylor skill score (TSS) is used to assess model skill. Wang et al. (2018) defined TSS as given in equation 1; 
$T S S=4(1+P C)^{2} /\left[\left(\frac{\sigma_{\text {cmip }}}{\sigma_{\text {chirps }}}+\frac{\sigma_{\text {chirps }}}{\sigma_{\text {cmip }}}\right)\left(1+P C_{0}\right)^{2}\right]$

where PC is the pattern correlation coefficient between the model outputs and observation. The

$\mathrm{PC}_{0}$ is the highest $\mathrm{PC}$ achievable (here, we set the threshold at 1). Also, variable such as $\sigma_{c m i p}$ and $\sigma_{\text {chirps }}$ represent SSD of the simulated and observed patterns, respectively. The score $\sim 1$ threshold value shows a perfect association between model and observed whereas 0 expresses contrary model performance. Successful application of this technique has been utilized in various studies (e.g., Luo et al., 2020; Xin et al., 2020; Zhu et al., 2020).

Lastly, portrait diagram depicting the RMSEs for each model is derived by first computing the multimodel mean and median for each index and then calculated relative to its RMSE. More information regarding the computational of this approach can be obtained from the works of Sillmann et al. (2013).

\section{Results and discussion}

\subsection{Climatology of mean and precipitation indices}

As a first step, this study examined the characteristics of the monthly precipitation rate over East Africa as simulated by CMIP6/5 against the observed data. The annual cycle of model simulation and their multimodel ensemble mean relative to CHIRPS is presented in Figures 2 and 3. Over EA, the CHIRPS demonstrate a bimodal pattern with peaks during MAM and OND. The months of June - September (JJAS) are relatively dry seasons, with the month of July considered as the driest month, reflecting $<1 \mathrm{~mm} /$ day precipitation rate over the most region. The two peaks showed in the observed data are mostly associated with the tropical rain belt that oscillates from $15^{\circ} \mathrm{S}-15$ ${ }^{\circ} \mathrm{N}$ throughout the year (Nicholson, 2018). Notably, the CMIP6 shows improved simulation of MAM season compared to CMIP5, which shows the inability of models to perfectly capture the rainfall patterns during aforementioned season (Figure 2). Moreover, enhancement is further noted in the reproducibility of OND peak in CMIP6 with notable models such as NorESM2-MM, CNRM-CM6-1, and MPI-ESM1-2-LR able to simulate the peak satisfactorily. Comparative analysis of model's performance in the simulation of the two peaks for CMIP6 and CMIP5 reveal varying performance. Significantly, the two model outputs vastly overestimated the OND peaks, with CMIP5 depicting overestimations by all models, including the MME (Figure 3). Interestingly, 
the CMIP6-MME robustly mimicked the two tips of MAM and OND season, unlike CMIP5MME. This shows better reproducibility of annual rainfall over study region by new model generation.

Generally, relatively dry bias is reflected in MAM season, with CMIP5/6 showing underestimations. Existing studies have remarked on the challenge of CMIP precipitation models' trend to manifest wet (dry) bias during OND (MAM) rainy season over the study domain (Otieno and Anyah, 2013; Ongoma et al., 2018b; Mumo et al., 2020). The pronounced dry biases during MAM (Figure 2 and 3 ) could be as a result of observed a reduction in seasonal precipitation (Funk et al., 2008; Lyon and Dewitt, 2012; Liebman et al., 2014; Ongoma et al., 2017; Ayugi et al., 2018). The exact causation of the declining patterns remains a challenge to accurately identify due to the weak correlation with large SST anomalies (Liebman et al., 2014). Summary results from most studies have narrowed to the impact of the west to central Pacific and the western Indian Ocean as the significant contributor to the observed decline (William and Funk, 2011; Liebman et al., 2014; Ayugi et al., 2018). The resultant impact of the observed decline has affected many communities who continue to rely on rainfed agro-based economy as means of livelihood due to the impact of drought increase (Adhikari et al., 2015; Mumo et al., 2018; Ayugi et al., 2020a). Thus, alternative solutions must be devised to cope with the dry patterns reflected in CMIP5 and CMIP6 over the region. With the models' well-pronounced ability to reproduce the MAM rains, the future projection of its likelihood will be of great importance to the country's economy.

On the contrary, OND precipitation shows many wet biases during the recent decades as is well reproduced in both model ensemble (Fig. 2 and 3). The findings agree with previous findings (Hastenrath et al., 2011; Ongoma et al., 2017). Compared to the long rains, the OND is strongly correlated to the meridional and vertical circulations cells in the central Indian Ocean, in addition to the intensified upper-level subsidence over east Africa (Mutai et al., 2012; Nicholson, 2015). The shift of overestimation (underestimation) in OND (MAM) precipitations could be well attributed to the collocation of dynamical factors that impacted the changes in the Indian Ocean against the Atlantic Ocean, resulting in observed flood (droughts) during OND (MAM) (Liebman et al., 2014; Nicholson, 2015). The ability of models to reflect such changes shows strong skills of models in reproducing East Africa's climate. Past studies have reported a paradox scenario with the long rains, which needs to be addressed. Nevertheless, the overestimation of the OND rains 
can negatively impact farmers as they would expect more rainfall, and it turns out to be less expected.

Despite the ensemble mean showing an aspect of underestimations in both seasons in CMIP6/5, it outdid most individual models to depict closer performance as observed (Figure 2 and 3). Typically, the study shows an improved performance in CMIP6 in the local annual mean cycle simulation with a better representation of two peaks, especially the MAM. The models NorESM2MM showed a remarkable performance in the annual cycle simulation over the study area (Fig. 2). Comparative studies across other regions globally equally show varying performances with some studies depicting improved performance by CMIP6 models and their ensembles (Xin et al., 2020; Zhu et al., 2020; Zamani et al., 2020), while unsatisfactory performance of CMIP6 in simulating annual precipitation is pointed over Tibetan Plateau in China (Zhu and Yang, 2020). 

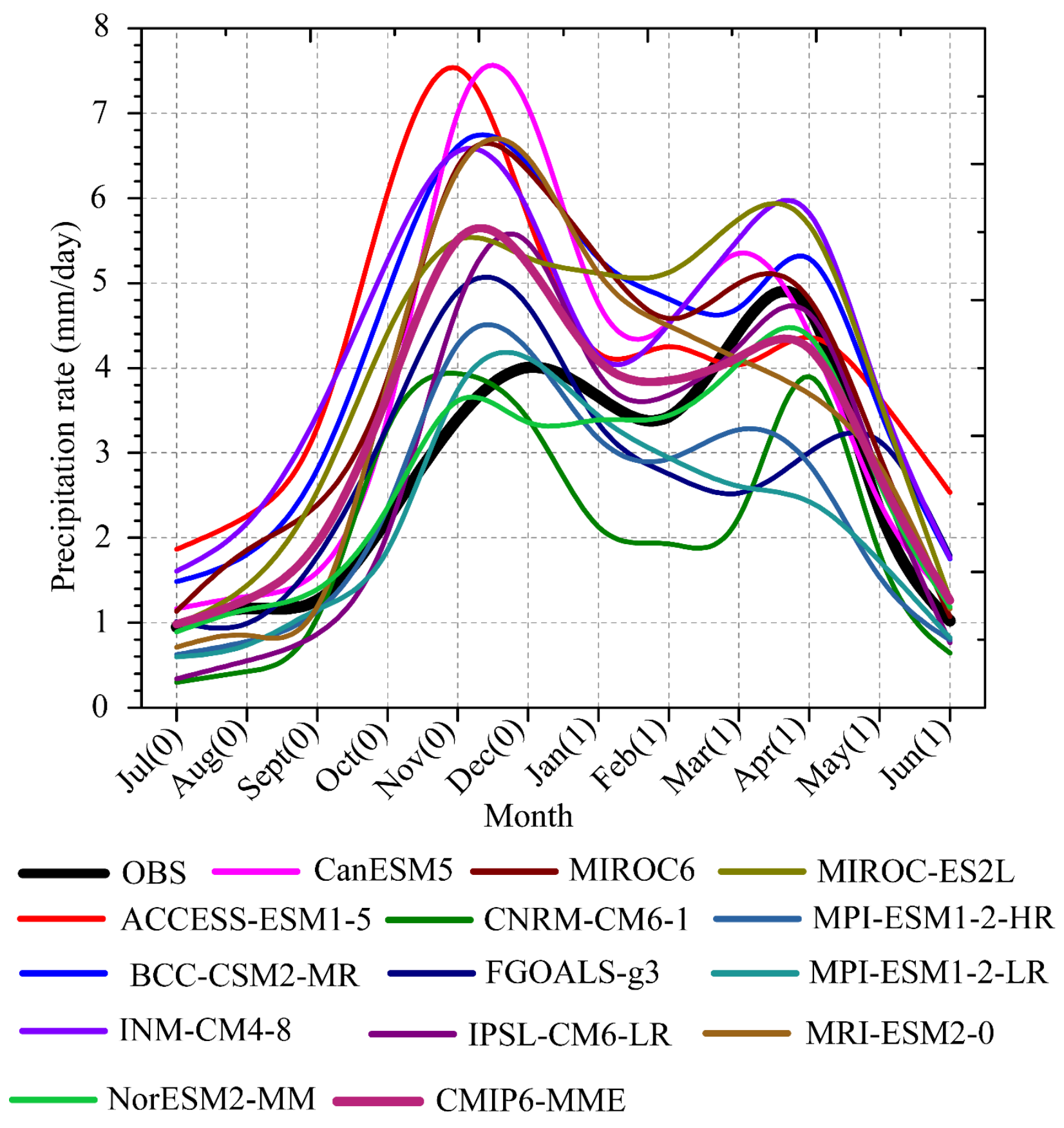

Figure 2. Mean annual precipitation (mm.day-1) during 1981-2005 for the CMIP6 models, MME, and observation over East Africa. 


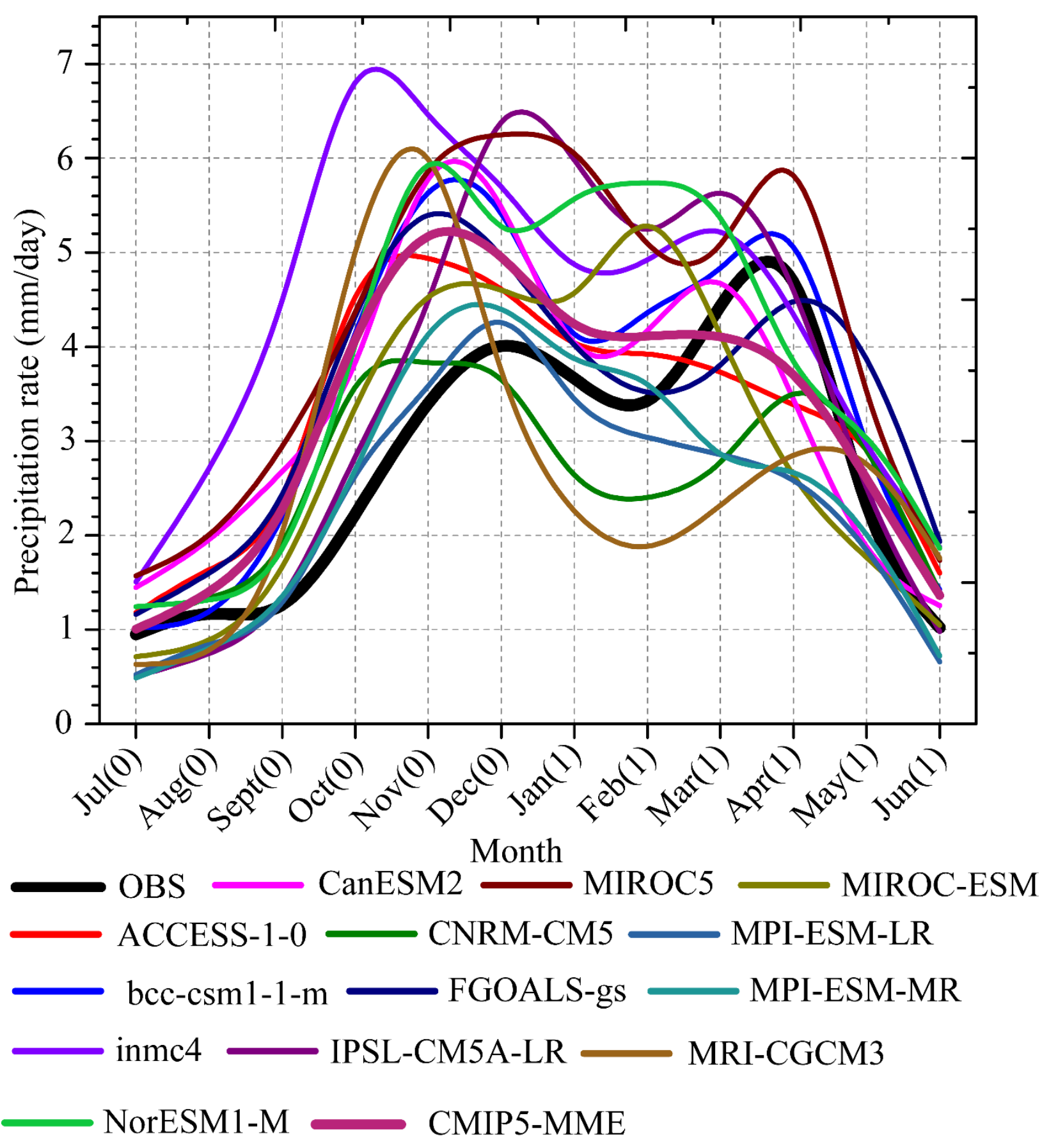

Figure 3. As Fig. 3 but for CMIP5 models.

\subsection{Spatial patterns of precipitation extremes}

A comparative analysis of model performance in the reproducibility of the observed seasonal climatology of precipitation indices for MAM and OND over the study region is shown in Figure 4 and 5. The spatial distribution of the precipitation biases of five extreme indices used (Table 2) 
and the respective boxplots are shown for the period $1981-2005$. The results show performance of CMIP6-MME of 13 models in the simulation of observed extreme events as compared to its predecessor. The model ensemble for MAM season indicate aspect of underestimation for most indices except for CDD over the study area (Figure 4). The OND season show overestimation of most precipitation indices except for SDII and R20mm (Figure 5). CMIP5 depict largest areal mean relative bias relative to CMIP6 in total precipitation with $28 \%$ as compared to $21 \%$ in CMIP6 for MAM precipitation. Besides, OND shows smaller areal mean relative bias in CMIP6 as compared to its predecessor (Figure 5). Other indices highlight the biases of $8.1 \%$ (1.0\%) for R95p, SDII (- $3.9 \%$ ) (-4.2), and R20mm (- 0.8 days) (-1.0 days) while OND depicts biases of 29.8 $\%$ (21.6\%) for R95p, SDII (-2.2\%) (-2.3), and R20mm (0.6 days) (0.1 days) (Figures 4 and 5). This suggests that while the CMIP6 models simulated large biases in PRCPTOT and R95p, the models outperformed the CMIP5 models with lesser negative biases in SDII, R20mm, and CDD (as Figure $4 \mathrm{~g}, \mathrm{j}$ and $\mathrm{m}$ illustrate).

In agreement with previous studies (i.e., Osima et al., 2018; Ogega et al., 2020), the GCMs show an underestimation of CDD, and R20mm, especially over eastern Kenya and northeastern Tanzania, where model agree significantly. Related study at the global level (Chen et al., 2020), equally observed persistent underestimation of R20mm and CDD in CMIP models. The study attributed the simulated biases to increased biases in CMIP6 models as compared to CMIP5 models. The remarkable negative bias for CDD is mainly as a result of poor simulations by models such as INM-CM4 (26 days) and MIROC-ES2L (30 days) (not shown here). Chen et al. (2020) attributed the notable underestimation of CDD to the increased spatial resolution in CMIP6 models, thereby capturing more precipitation that is often simulated at a much finer scale by highresolution models. Notably, western Uganda shows a substantial bias of overestimating heavy precipitation days despite underestimating in most regions during MAM (Figures 4k, 1, m, and n), and OND (Figures 5k, 1, m, and n). Furthermore, bias in PRCPTOT is exceeding $200 \mathrm{~mm}$, R95p is $>40 \mathrm{~mm}$, and $-10.8 \mathrm{~d}^{-1}$ for CDD, respectively. This could be due to moist westerlies originating from the Congo basin resulting in enhanced rain during the wet seasons in the north and southwest when other parts of the country are cold and dry (Mchugh 2004; Kizza et al. 2009). 

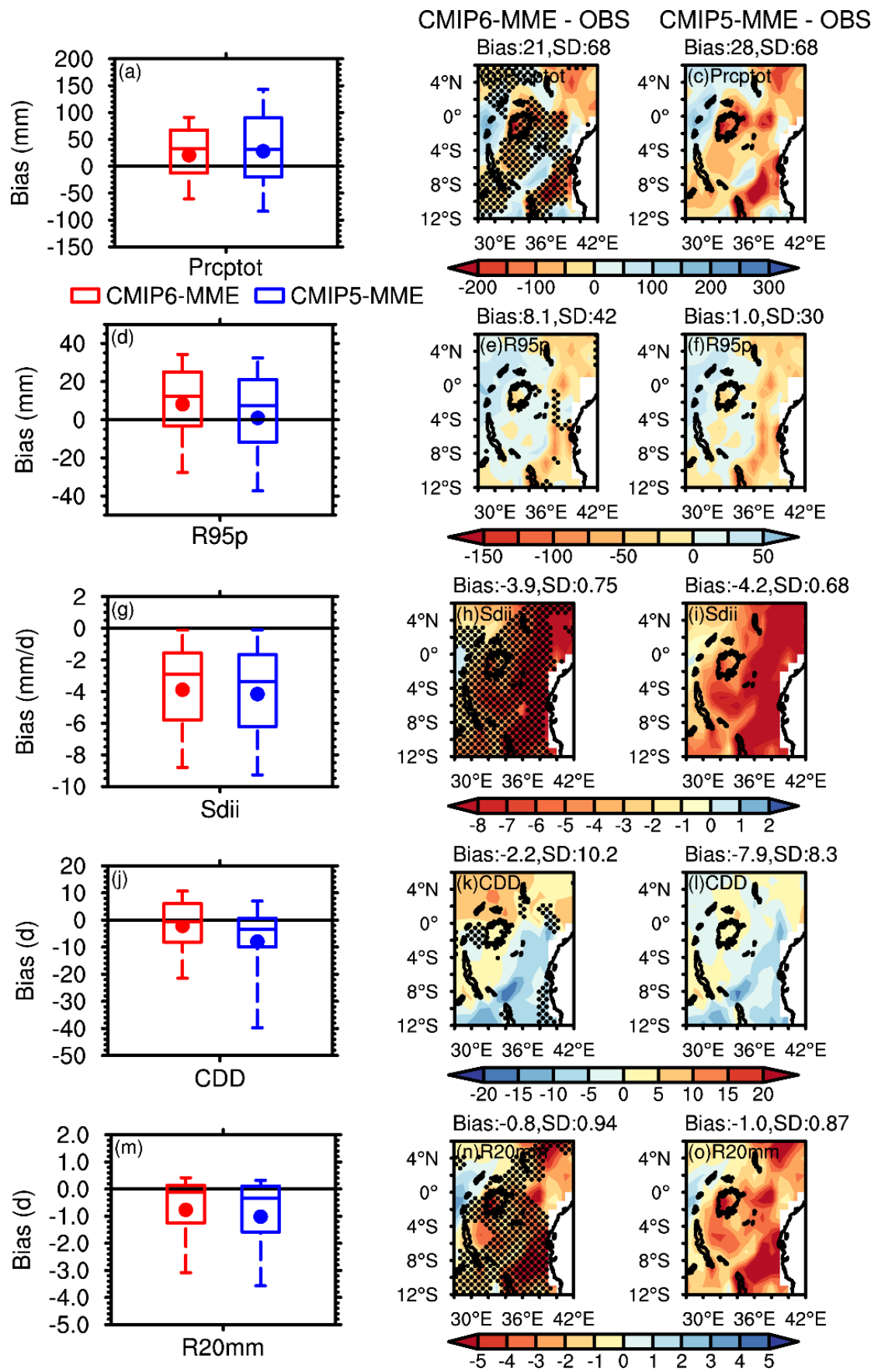

Figure 4. Box-and-whisker plots (left column) and the spatial pattern of biases (simulation minus observation) in CMIP6- MME (middle column, red) and CMIP5-MME (right column, blue) of March - May (MAM) precipitation indices for the historical period, 1981-2005. From top to bottom are but for (a-c) Prcptot, (d-f) R95p, (g-i) Sdii, (j-1) CDD and (m-o). R20mm (units: mm, $\mathrm{mm}, \mathrm{mm} \mathrm{d}^{-1}, \mathrm{~d}, \mathrm{~d}$ ). The areal-mean bias (Bias) over East Africa and the intermodel SD of the difference averaged over the country (middle and right column) are given on the top of each panel (but with bias and internel SD of the difference for R20mm; units: d). 
Numerous studies have pointed the challenge of simulating precipitation variable as compared with temperature (Almazouri, 2020; Chen et al., 2020; Jiang et al., 2020; Zhu et al., 2020). This is mainly associated to the issues related to model parameterization, especially in regions with complex physiographical features such as East African region or challenges related to local mesoscale features such as lakes, vegetation cover or large coastline that causes regional heterogeneity (Nikulin et al., 2012). Generally, the comparison between the CMIP6-MME and CMIP5-MME over EA region depicts varying performance with improvement in the simulation of some indices (i.e. SDII, R20mm, and CDD) while no significant improvement is noted in reproducibility of extremely wet days for seasonal precipitation. Essentially, the new models depict small biases, such as PRCPTOT (Figure 4a), during MAM with lower amplitude of < 100 $\mathrm{mm}$ as compared with $>150 \mathrm{~mm}$ in CMIP5-MME. However, higher amplitude is observed in the simulation of PRCPTOT during OND (Fig. 5), with > 250 mm in CMIP6-MME relative to CMIP5MME which exhibit bias of $200 \mathrm{~mm}$ in the simulation of total precipitation. The areal-mean bias has reduced in MAM (OND) by $7 \%$ (23\%). Interestingly, the dry biases shown in CMIP5-MME over eastern Kenya and southern Tanzania are enhanced in CMIP6-MME with model agreements demonstrated by significant score for annual precipitation (Figures 4e, and f). Remarkably, most regions that portrayed either dry/wet biases are reflected in both CMIP6-MME and CMIP5-MME except that the CMIP6-MME showed statistically significant changes at the 95\% confidence level in such regions. Substantial dry biases are observed during MAM and OND for SDII with CMIP6MME depicting robust changes (Figures 4h, i; figures 5h, i). Notably, most model show agreement on the significant changes over Kenya and Tanzania region in the simulation of precipitation indices except for R95p in both annual and seasonal performance.

The result of the present study indicates that the CMIP6-MME shows overestimation (underestimation) of PRCPTOT, R95P (SDII, CDD, R20mm) extreme precipitation events over most regions as compared to CMIP5-MME for OND season. Conversely, MAM simulation indicate underestimations of most indices excluding CDD. Particularly, the simulations of SDII, CDD and R20mm are closer to the observation as compared with the CMIP5 simulation which is an indication that the performance of the CMIP models varies with extreme precipitation indices. The results show an improvement in seasonal simulation, particularly for MAM season as compared to OND rains over the study region. The systematic overestimation (underestimations) 
in mean precipitation is equally observed in other similar evaluative studies over Tibetan Plateau and East Asian Monsoon region (Jiang et al., 2020; Zhu and Yang, 2020).
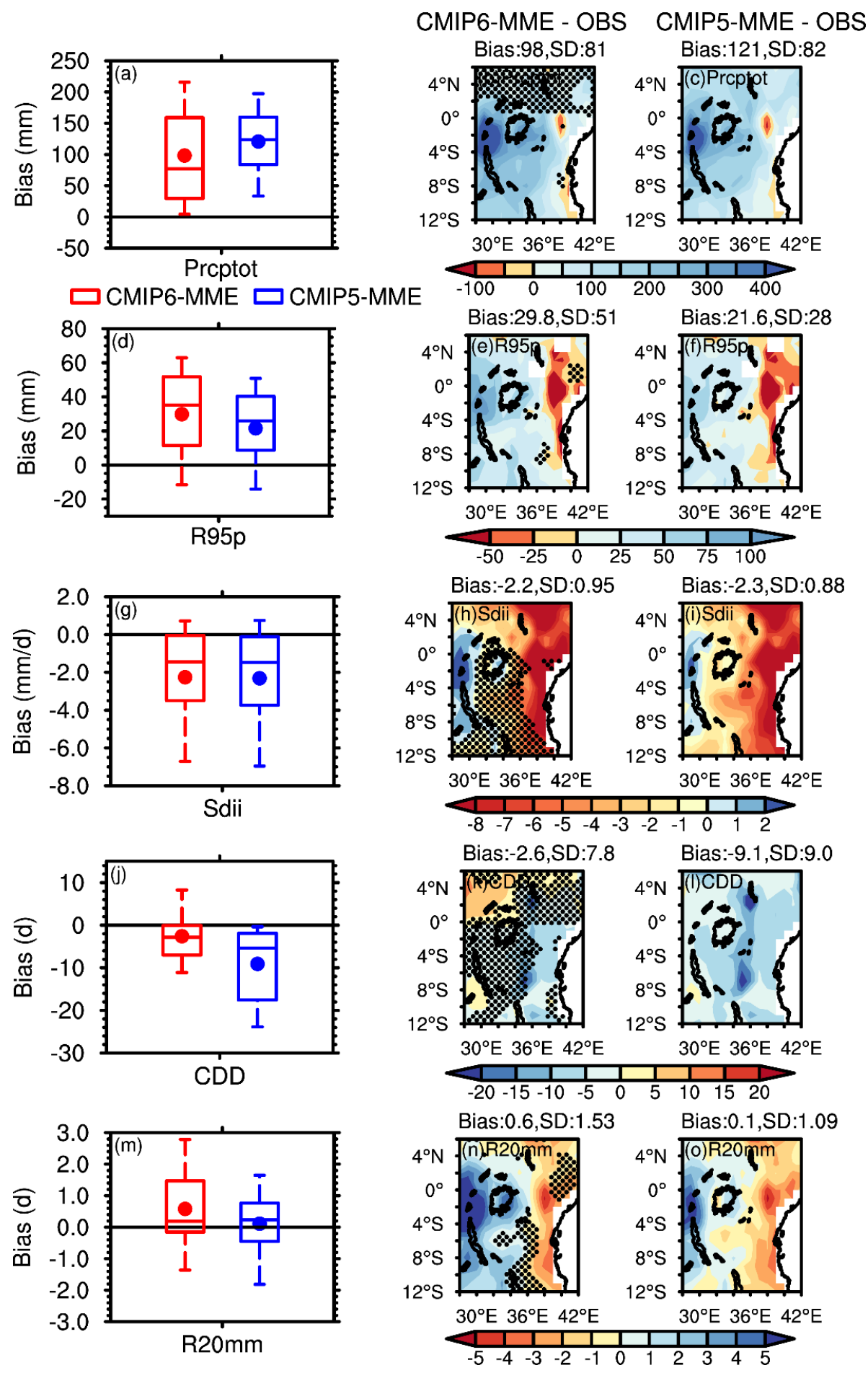

Figure 5. Same as Fig. 4 but for October - December (OND).

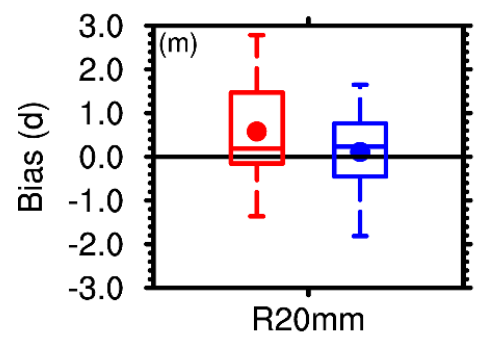


Figure 6 and 7 demonstrates a summary of model performance for MAM (OND) climatology as represented in the Taylor diagram (TD) and TSS for all indices simulated in the present study. The TD highlights the statistical feature of individual models and MME of 13 CMIP5 and CMIP6 models relative to the observations. Comparative analysis for seasons shows an excellent simulation of all indices during MAM relative to OND (Figure 6). The SCC during MAM season for all indices in CMIP6-MME equated to CMIP5-MME depict robust simulation with PRCPTOT (0.92/0.85), R95p (0.6/0.58), SDII (0.34/0.30), CDD (0.75/0.60), and R20mm (0.6/0.54) (Figure 6). Similarly, the OND season exhibited improved performance, with most models and MME showing satisfactory performance for CMIP6-MME against CMIP5-MME (Figure 7). The SCC for PRCPTOT (0.93/0.91), R95p (0.4/0.3), SDII (0.40/0.32), CDD (0.95/0.94), and R20mm (0.60/0.62). Interestingly, the SDII (Figures 6, and 7) showed lowest SCC/SSD $(<0.3 /<1$ ) for both CMIP6/5 in most individual models, indicating reduced inter-model uncertainty.

Additional examination of the CMIP6/5 models based on TSS shows a better representation of most indices during seasonal climatology in the latest model outputs. Results for MAM (figure 6) show higher TSS for CMIP6-MME in all indices, while OND demonstrates the unsatisfactory simulation of R20mm and PRCPTOT in CMIP6-MME (figure 7). Significantly, the R95p demonstrated less skill with TSS value for CMIP5/6 at 0.4/0.44 (Figure 7f). Comparative analysis of CMIP6/5 for PRCPTOT showed a better score in CMIP5-MME for OND while R20mm markedly showed minor improvement during OND season (Figure 7f).

The results show the capability of GCMs to robustly simulate the spatial pattern of most precipitation indices over the study area. CMIP6-MME demonstrate vigorous outputs in the simulation of precipitation indices during MAM season while varying results are depicted for OND season. Enhanced simulation during MAM season is demonstrated in CDD, SDII, and R20mm, despite the low spatial correlation. At the same time, OND poorly represent total precipitation days and extremely wet days. Overall, the performance of the CMIP6 ensemble demonstrates satisfactory performance in the simulation of most extreme events over the East Africa region compared to CMIP5 models. Simulations for R95p and SDII remains a challenge over EA in CMIP6 models. 
(a)Prcptot

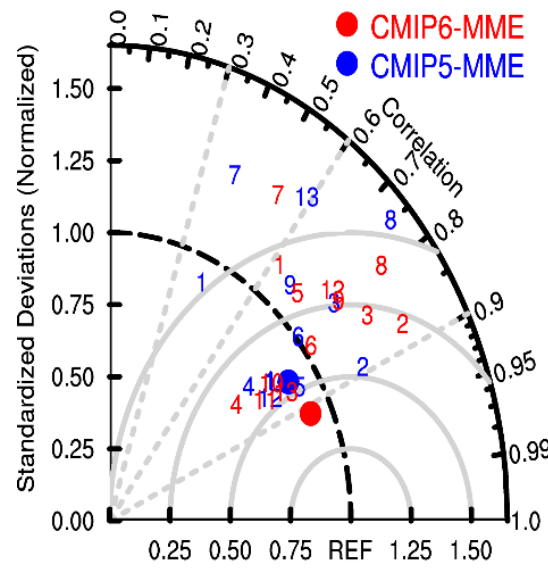

(d) CDD

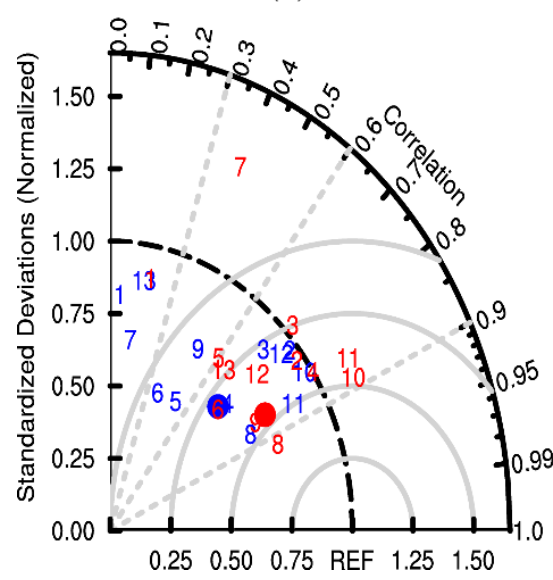

(b)R95p
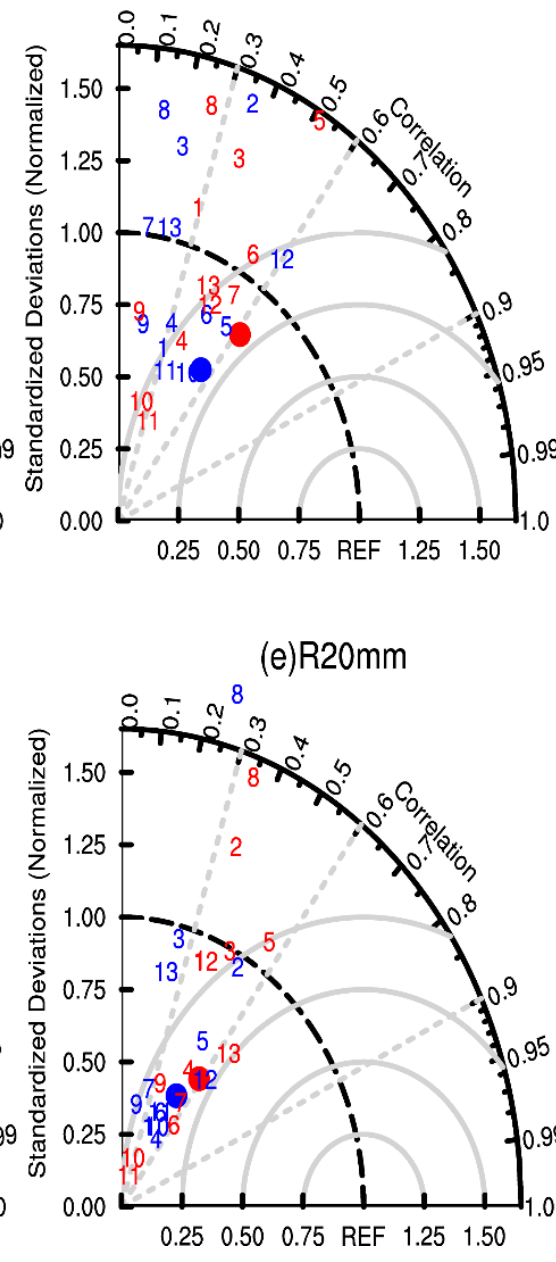

(e) $\mathrm{R} 20 \mathrm{~mm}$

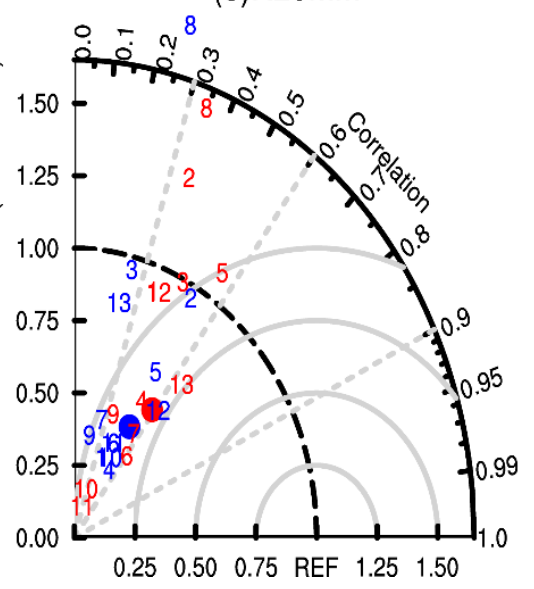

(c)Sdii

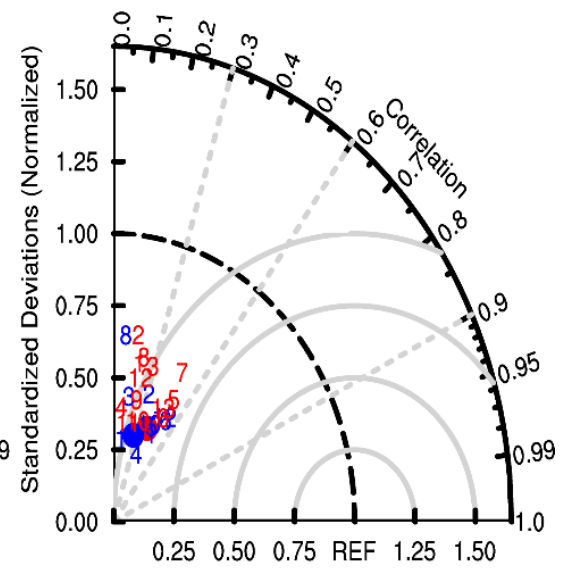

(f)Taylor Score

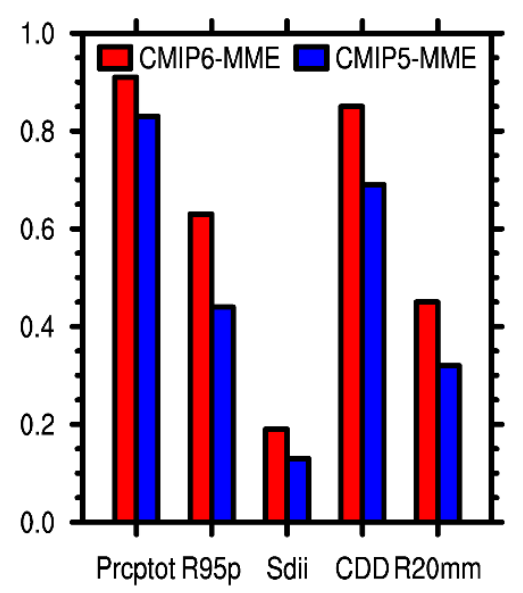

Figure 6. Taylor diagrams (a-e) and skill scores in terms of TSS (f) showing the performance of models (CMIP6 in red, CMIP5 in blue) in simulating March - May (MAM) climatological fields over East Africa for five precipitation indices. Angular axes show pattern correlation coefficients between simulated and observed fields; radial axes show the spatial centered RMSE (normalized against the observed). Blue and red numbers indicate CMIP5 and CMIP6 models listed in Tables $\mathrm{S} 2$. The larger solid circles represent the MME. The scale represents the precipitation indices used. 
(a)Prcptot

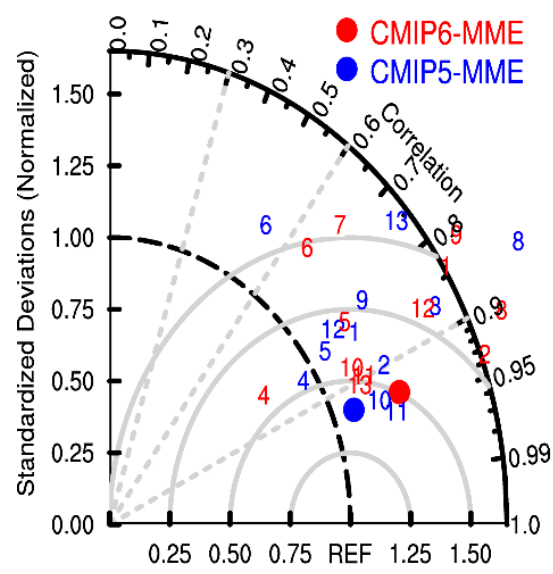

(d)CDD

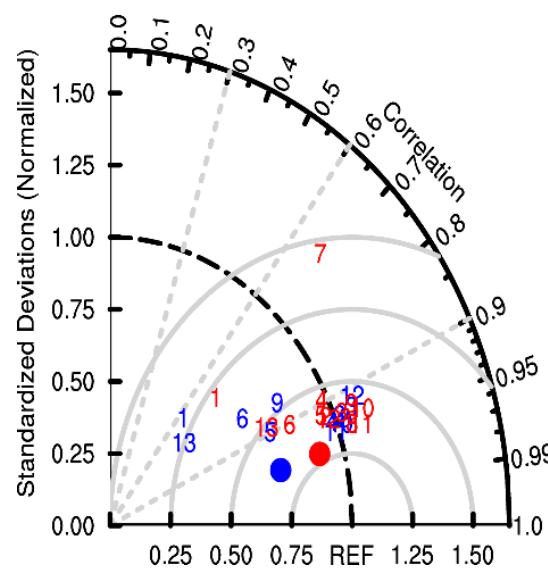

(b) R95p

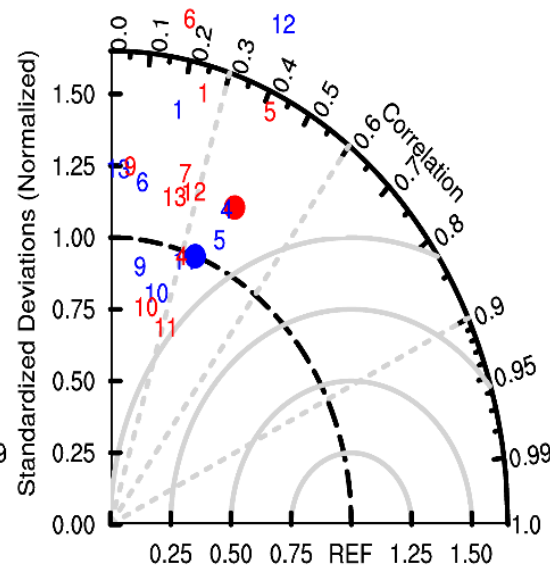

(e)R20mm

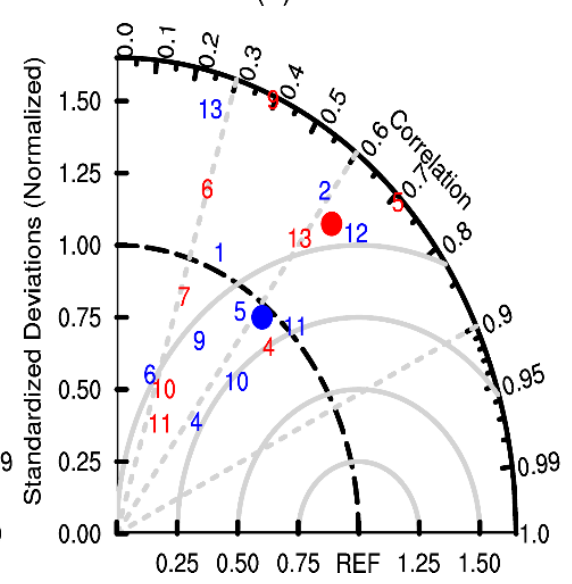

(c)Sdii

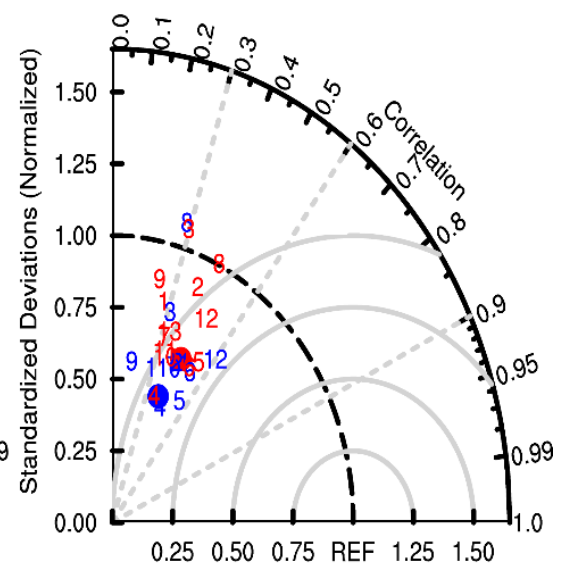

(f)Taylor Score

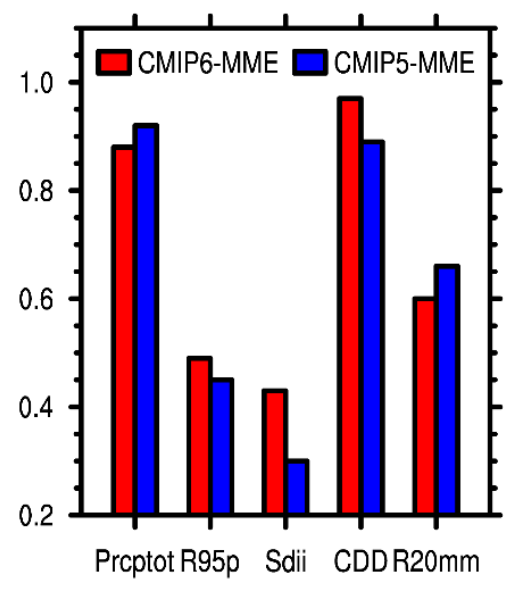

Figure 7. Same as Fig. 6 but for October - December (OND).

A portrait diagram that gives a summary for all individual model performance in simulating the precipitation extremes indices for MAM and OND is presented in Figures 8 and 9 respectively. The portrait highlights the regional mean RMSE for each index (PRCPTOT, SDII, CDD, R20mm, and R95p) depicted in rows and for 26-CMIPs models in columns. Precipitation indices are represented by CMIP6 (red) and CMIP5 (blue) models from the same institution with respect to the observation. The colder color series indicate that model performance better whilst warmer color denotes models with relatively low skills on average. Moreover, CMIP5/6-MME is equally evaluated and presented in the last two columns of the portrait diagram.

Analysis shows that few CMIP6 models (e.g., NorESM2-MM, and CNRM-CM6-1) depict robust performance in reproducing the observed indices across all analyses. The majority of the CMIP6 models show substandard performance with most models depicting warmer colors. 
However, comparative analysis shows improved performance during MAM relative to OND in the CMIP6 models.

CMIP6

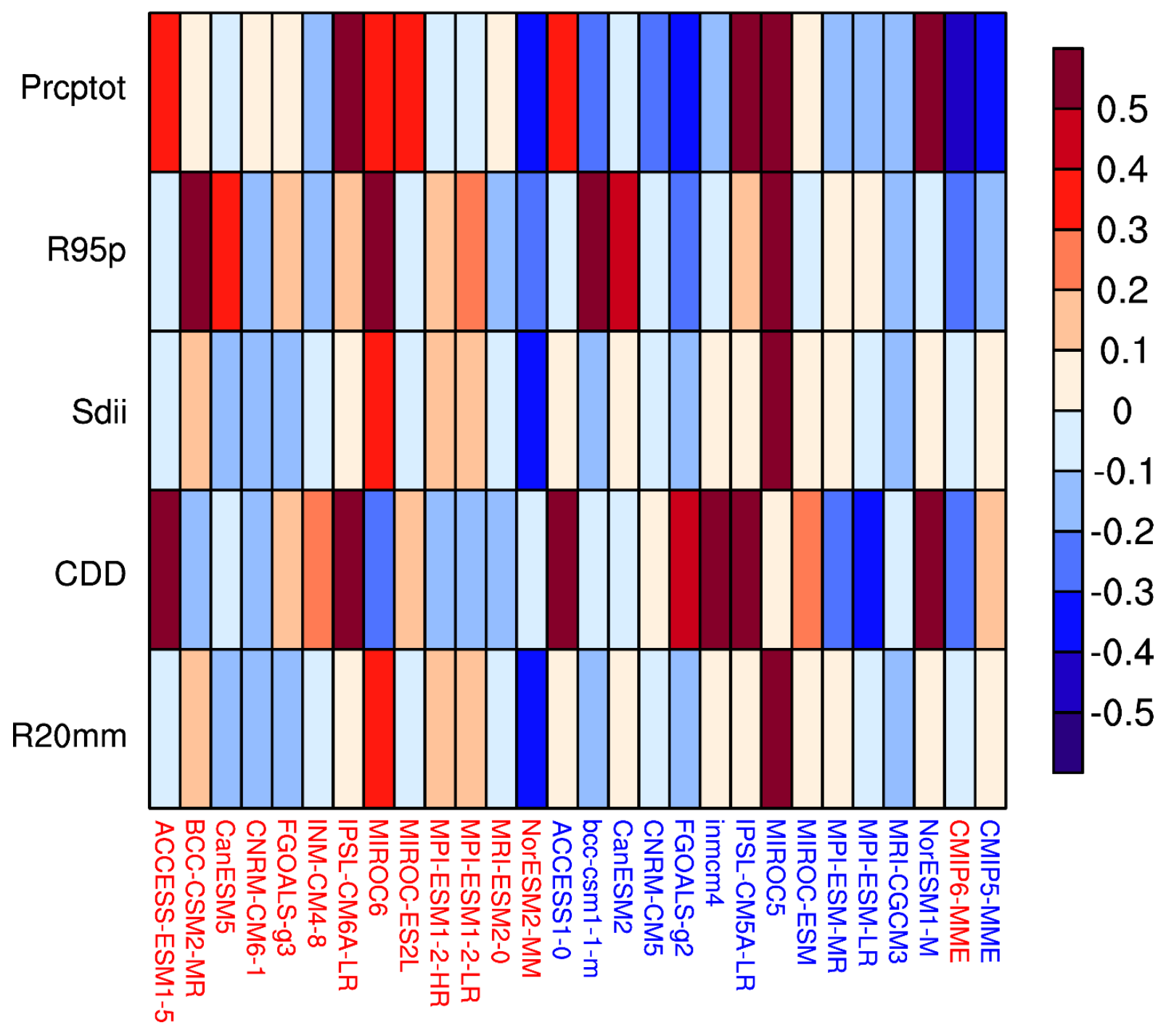

Figure 8. Portrait diagram of relative spatially averaged RMSEs in the 1981-2005 of March May (MAM) climatologies of precipitation indices simulated by CMIP6 (red) and CMIP5 (blue) models from the same institution with respect to the observation

Consistent with other studies, the performance of mean ensemble for both CMIP5/6 shows better performance due to the cancellation of some systematic errors in the individual models (Sillman et al., 2013). While it is widely expected that the new improvements in the latest model outputs ought to translate to reduced uncertainity, the CMIP6-MME continue to exhibit substandard performance relative to CMIP5-MME. Predominantly, most models showed weak performances in the simulation of some in both CMIP5/6. The models that exhibited better 
performance in reproducing the observed extreme occurrences for CMIP6 during MAM rainfall are as follows: NorESM2-MM, MRI-ESM2-0, and CNRM-CM6-1 while for CMIP5 are: MPIESM-LR, MPI-ESM-MR, CNRM-CM5, and MRI-CGCM3 (Figure 8). Only the models (NorESM2-MM, MPI-SM1-2-HR, and MPI-SM1-2-LR) exhibited persistence performance in the latest model outputs during OND season (Figure 9). MIROC6, and ACESS-ESM1-5 showed unsatisfactory simulation during MAM, and OND for most indices over the study area. Overall, most CMIP6 models are unable to simulate the extremely wet days (R95p) during MAM climatology.

\section{CMIP6}

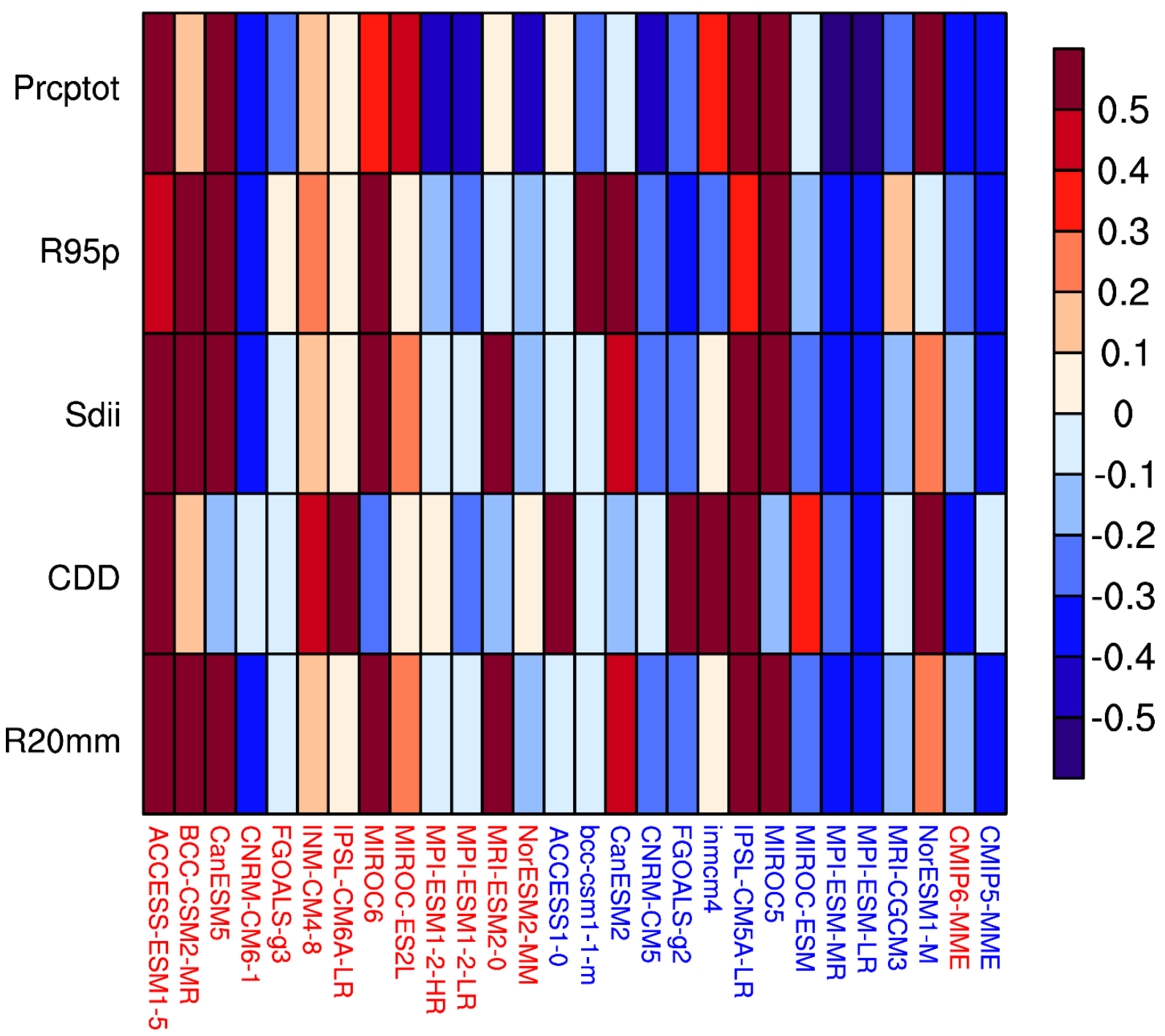

Figure 9. Same as Fig. 8 but for October - December (OND). 


\section{Discussion}

The present study assesses performance of the new GCMs of CMIP6 against its predecessor in the simulation of mean annual climatology and extreme events during MAM and OND over the EA region. Besides, the study examines whether the uncertainty is narrowed in CMIP6 compared to CMIP5. This was achieved by associating the GCMs with observational datasets obtained from the Climate Hazards Center (CHIRPSv2). The assessment was conducted in terms of spatial patterns and temporal variability for the period 1981 - 2005, reflecting the starting year of observed datasets and ending year for CMIP5 ensemble models. The study employed robust skill score techniques such as Taylor diagram and TSS denoting the spatial variability, and portrait diagram depicting the RMSEs for each model. The analysis was mainly based on the MME derived by computing simple arithmetic mean of individual models for two seasons. Likewise, the study employed five subsets of precipitation indices obtained from ETCCDMI.

Our results indicate the new ensemble models' satisfactory performance in simulation of two tips of MAM and OND season, despite aspects of overestimations depicted by most models. Previous studies that assessed the performance of CMIP5 over the region observed underestimation of annual mean climatology and MAM season while overestimations of short rains occurring during OND (Yang et al., 2015; Ongoma et al., 2018b). The CMIP6, on the contrary, presents an improvement in the simulation of MAM rainfall and few models reproducing OND peaks (Figure 2). Further assessment of precipitation indices shows enhancement of CMIP6 models in representing MAM rainfall comparable to OND (Figures 4 - 7). The possible attributions to the results in the present study could be associated with aspects of improved spatial resolutions of models (Eyring et al., 2016) that can capture local convective systems that could not otherwise be registered in the previous GCMs that had courser spatial resolution (Taylor et al., 2012). Most significantly, parameterization in the GCMs plays an essential role in the biases observed from one region to another (Flato et al., 2013; Stouffer et al., 2017). The CMIP5 featured aspects of inability to represent the local climate, which could be attributed to poor parameterization schemes and courser spatial resolutions (Kisembe et al., 2018; Ongoma et al., 2018b; Ayugi et al., 2020b; Mumo et al., 2020). The case of overestimation by most CMIP6 models and their respective ensembles (Figures 3 and 5), could be attributed to the systematic biases resulting from intermodel weaknesses in their framework schemes (Wu et al., 2019; Volodin et al., 2019; Tatebe et al., 2019). Similar results have been observed in related studies conducted 
over Tibetan Plateau (Zhu and Yang, 2020). Notably, the complex geomorphology that distinguishes the Tibetan region is also present in the study area. For instance, the high mountains (e.g., Mt. Kilimanjaro, Mt. Kenya, Mt. Elgon, and Mt. Ruwenzori), with an elevation of $>4000$ m.s.l play a significant role in enhancing mesoscale features, which are in turn reflected in models with high resolutions ( $70 \mathrm{~km}$ ) (Indeje et al., 2000; Ogwang et al., 2014). The precipitation indices (i.e., R95p), which persistently remained poorly represented (Figures 4, and 5), show the failure of CMIP6 models to represent extreme wet days in OND season.

The resultant impact could be detrimental to the local community where climate change effects resulting in extremes events such as floods lead to the destruction of properties and livelihoods. Attributions to the unskillful simulation of some indices (i.e., R95p), is contributed to mainly by the unsatisfactory performance of individual models (i.e., MIROC6) that demonstrate large biases in the reproducibility of extreme events. The main improvement in the new generation model (MIROC6) is mainly in the model's ocean biogeochemical component that has been primarily updated to simulate the biogeochemical cycles of carbon, nitrogen, phosphorous, iron, and oxygen (Hamija et al., 2020).

Despite the robust findings of this study, varying limitations are noted, influencing the current results. Examples entail issues such as the limited number of models evaluated (i.e., thirteen models from CMIP5/6), the statistical approach employed, and the restricted number of indices considered. Nevertheless, the results point to two main directions. Firstly, the improvement in MAM rains simulation presents a promising future of accurate forecast of future climate. The CMIP5 models and subsequent climate analyses established a climate paradox situation where models showed contrary patterns to the observed scenarios. This caused confusion and a lack of consensus on the future state of the regional climate for suitable policy formulation and adaptation.

On the contrary, the latest models' inability to accurately simulate some extreme events and persistent overestimations of OND peaks highlights situation uncertainty and calls for in-depth studies on the causation of the inability of models to simulate the OND peaks robustly. Persistent uncertainty exposes various stakeholders such as policymakers and users of climate information to remain in a state of indefinite future climate projections for OND rainfall since the model's reliability cannot be wholly trusted. This calls for further investigation and attribution studies into the sources of unyielding systematic biases. The weakened performance in CMIP6 models over the East African region calls for cautionary in climate studies with the need for assessment studies 
to identify the individual models with robust features to accurately simulate observed patterns for future usage.

\section{Summary and Conclusion}

The main findings of the present study can be itemized as follows:

1. The CMIP6 models show improved performance in the simulation of mean and extreme precipitation over East Africa relative to CMP5 models. Particularly, the CMIP6-MME vigorously reproduce two tips of bimodal pattern, relative to CMIP5 models. For seasonal climatology, CMIP6 models exhibits robust performance in the simulation of MAM season and improved reproducibility of OND season, with notable models such as NorESM2-MM, CNRM-CM6-1, and MPI-ESM1-2-LR capable to simulate the peak satisfactorily relative to CMIP5. Despite the ensemble mean showing an aspect of underestimations in both seasons in CMIP6/5, it outdid most individual models to depict closer performance as observed. For instance, the CMIP6-MME robustly mimicked the tip of MAM season, unlike CMIP5-MME. This shows better reproducibility of MAM rainfall over study region by new model generation.

2. The performance of CMIP6-MME varies as compared to CMIP5-MME in the simulation of extreme indices. The model ensemble for MAM season indicate aspect of underestimation for most indices except for CDD over the study area while OND season shows aspect of overestimation of some indices (i.e., R95p, PRCPTOT), except for SDII, CDD and R20mm. Nonetheless, the CMIP6-MME performed better than the CMIP5-MME with lesser biases in simulating SDII, CDD, and R20mm over East Africa. To illustrate, the CMIP5 depict largest areal mean relative bias relative to CMIP6 in total precipitation with $28 \%$ as compared to $21 \%$ in CMIP6 for MAM precipitation. Other indices highlight the biases of $8.1 \%$ (1.0\%) for R95p, SDII (- $3.9 \%)$ (-4.2), and R20mm (- 0.8 days) (-1.0 days) while OND depicts biases of $29.8 \%$ (21.6 \%) for R95p, SDII (-2.2\%) (-2.3), and R20mm (0.6 days) (0.1 days). This suggests that while the CMIP6 models simulated large biases in PRCPTOT and R95p, the models outperformed the CMIP5 models with lesser negative biases in SDII, R20mm, and CDD. Remarkably, most CMIP6 models are unable 
to simulate the extremely wet days (R95p) while satisfactory simulation of CDD is noted in new model outputs over the study region.

3. A few CMIP6 models (e.g., NorESM2-MM, and CNRM-CM6-1) depicts robust performance in reproducing the observed indices across all analyses. Majority of the CMIP6 models are still marred with uncertainity. Consistent with other studies, the performance of mean ensemble for both CMIP5/6 show better performance due to the cancellation of some systematic errors in the individual models. Generally, the CMIP6 depict improved performance in the simulation of MAM season akin CMIP5 models. Moreover, simulation of extreme indices is well captured in CMIP6 models relative to its predecessor. Generally, little improvement is noted over East Africa domain in the new model generation despite the improved parametrization schemes, enhanced spatial resolution, and physical processes including the biogeochemical cycles (Eyring et al., 2016).

\section{Authors contributions:}

All authors made an equal contribution to the manuscript's development and consented to the submission for publication in the esteemed journal of theoretical and applied climatology. The following are individual contributions: B.A: conceptualization, formal writing, and original draft preparation. Z.H.H, V.D and H.B: Data curation, methodology, visualization. H.N and R.K: writing-review and editing, investigation. V.D: Validation, writing-review, and editing: Z.J: Validation, Funding, Supervising, and review.

\section{Acknowledgement and Funding Sources}

The authors acknowledge the World Climate Research Program (WCRP) Working Group on Coupled Models (WGCM) for availing the latest outputs from Coupled Model Intercomparison Project (CMIP) phase six. Financial and material support received from National Key Research and Development Program of China (Grant No. 2017YFA0603804 and 2018YFC1507704), National Science Foundation of China (No. 41805048).

\section{Compliance with ethical standards}

No conflict of interest is detected in this present study. All authors are in agreement with the content of the research. 


\section{References}

Adhikari, U., Nejadhashemi, A.P., Woznicki, S.A., 2015. Climate change and Eastern Africa: a review of impact on major crops. Food Energ. Secur., 4: 110-132. doi:10.1002/fes3.61

Ayugi, B.O., Tan, G., Ongoma, V., Mafuru, K.B. 2018. Circulations Associated with Variations in Boreal Spring Rainfall over Kenya. Earth. Syst. Environ. 2, 421-434. https://doi.org/10.1007/s41748-018-0074-6

Ayugi, B., Tan, G., Ullah, W., Boiyo, R., Ongoma, V., 2019. Inter-comparison of remotely sensed precipitation datasets over Kenya during 1998-2016. Atmos. Res. 225 (1), 96109.https://doi.org/10.1016/j.atmosres.2019.03.032

Ayugi, B., Tan, G., Niu, R., Dong, Z., Ojara, M., Mumo, L., Hassen, B., Ongoma, V., 2020a. Evaluation of meteorological droughts and wet scenarios over Kenya, East Africa. Atmosphere 2020, 11, 307. https://dio.org/10.3390/atmos11030307

Ayugi, B., Tan, G., Gnitou, G.T., Ojara, M., Ongoma, V., 2020b. Historical evaluations and simulations of precipitation over Eastern Africa from Rossby Centre Regional Climate Model. Atmos. Res. 232. https://dio.org/10.1016.jatmosres.2019.104705

Akinsanola, A.A., Zhou, W., 2019. Projections of West African summer monsoon rainfall extremes from two CORDEX models. Clim. Dyn. 52 2017.dio. 10.1088/1748/17489326/ab92cl

Almazroui, M., Saeed, S., Saeed, F., Islam, M.N., Ismail, M.,2020a. Projections of Precipitation and Temperature over the South Asian Countries in CMIP6. Earth Systm Environ. https://doi.org/10.1007/s41748-020-00157-7

Almazroui. M., Saeed, S., Saeed, F., Islam, M.N., Ismail, M., Klutse, N.A.B, Siddiqui, M.H.,2020b. Projected Change in Temperature and Precipitation Over Africa from CMIP6. Earth Systm Environ. https://doi.org/10.1007/s41748-020-00161-X

Cattani, E., Merino, A., Guijarro, J. A., Levizzani, V., 2018. East Africa Rainfall trends and variability 1983-2015 using three long-term satellite products. Remote Sens, 10, 1-26. https://doi.org/10.3390/rs10060931

Camberlin, P., Okoola, R.E., 2003. The onset and cessation of the "long rains" in eastern Africa and their interannual variability. Theor. Appl. Climatol.54(1-2), 43-54. https://doi.org/10.1007/s00704-002-0721-5.

Chen, H., Sun, J., Lin, W., Xu, H. 2020. Comparison of CMIP6 and CMIP5 models in simulating climate extremes. Science Bulletin. https://dio.org/10.1016/j.scib.2020.05.015

Collins, M., Knutti, R., Arblaster, J., Dufresne, J.-L., Fichefet, T., Friedlingstein, P., Gao, X., Gutowski, W.J., Johns, T., Krinner, G., Shongwe, M., Tebaldi, C., Weaver, A. J., Wehner, M., 2013. Long-term climate change: projections, commitments and irreversibility. In: Stocker, T.F., Qin, D., Plattner, G.-K., Tignor, M., Allen, S.K., Boschung, J., Nauels, A., Xia, Y., Bex, V., Midgley, P.M. (Eds.), Climate Change 2013:The Physical Science Basis. Contribution of Working Group I to the Fifth Assessment Report of the Intergovernmental Panel on Climate Change. Cambridge University Press, Cambridge, United Kingdom and 


\section{New York, NY, USA}

Dahinden, F., Fischer, E. M., Knutti, R. 2017. Future local climate unlike currently observed anywhere. Environ. Res. Lett, 12, 084004. Dio.10.1088/1748-9326/aa75d7

Dinku, T., Funk, C., Peterson, P., Maidment, R., Tadesse, T., Gadain, H. and Ceccato, P., 2018. Validation of the CHIRPS satellite rainfall estimates over eastern Africa. Q J R Meteorol Soc, 144, 292-312. https://doi.org/10.1002/qj.3244

Duan, A., Hu, J., Xiao, Z. 2013. The Tibetan Plateau summer monsoon in the CMIP5 simulations. J. Climate, 26, 7747-7766.Dio. 10.1175/JCL-D-12-00685.1

Endris, H.S., Lennard, C., Hewitson, B., Dosio, A., Nikulin, G., Panitz, H.J., 2015. Teleconnection responses in multi-GCM driven CORDEX RCMs over Eastern Africa. Clim. Dyn. 46(9-10), 2821-2846. https://doi.org/10.1007/s00382-015-2734-7

Endris, H.S., Lennard, C., Hewitson, B., Dosio, A., Nikulin, G., Panitz, H.J., 2016. Teleconnection responses in multi-GCM driven CORDEX RCMs over Eastern Africa. Clim. Dyn. 46(9-10), 2821-2846. https://doi.org/10.1007/s00382-015-2734-7

Eyring, V., Arblaster, J. M., Cionni, I., Sedláček, J., Perlwitz, J., Young, P. J., Faluvegi, G. 2013. Long-term ozone changes and associated climate impacts in CMIP5 simulations. J. Geophys Res-Atmos 118, 5029-5060. https://dio.org/10.1002/jgrd.50316

Eyring, V., Bony, S., Meehl, G.A., Senior, C.A., Stevens, B., Stouffer, R.J., Taylor, K.E., 2016. Overview of the coupled model Intercomparison project phase 6 (CMIP6) experimental design and organization. Geosci. Model Dev. (GMD) 9, 1937-1958. https://doi.org/10.5194/gmd-9-1937-2016.

FAO., 2019. The state of Food Security and Nutrition in the World 2019. Safeguarding against economic slowdowns and downturns. Rome, FAO. Licence: CC BY-NC-SA. 3.0 IGO

Flato, G., and Coauthors, 2013: Evaluation of climate models. Climate Change 2013: The Physical Science Basis. Contribution of Working Group I to the Fifth Assessment Report ofthe Intergovernmental Panel on Climate Change, T. F.Stocker et al., Eds., Cambridge University Press, 741-866, https://doi.org/10.1017/CBO9781107415324.020

Funk, C., Dettinger, M.D., Michaelsen, J.C,, Verdin, J.P., Brown, M.E., Barlow, M., Hoell, A., 2008. Warming of the Indian Ocean threatens eastern and southern African food security but could be mitigated by agricultural development. P. Natl. Acad. Sci. USA,105, 11081-11086. https://doi:10.1073/pnas.0708196105

Funk, C., Peterson, P., Landsfeld, M., Pedreros, D., Verdin, J., Shukla, S., Husak, G., Rowland,J., Harrison, L., Hoell, A., Michaelsen, J., 2015 The climate hazards infrared precipitation with stations - A new environmental record for monitoring extremes. Scientific Data2: 1-21. https://doi.org/10.1038/sdata.2015.66

Friedlingstein, P., Meinshausen, M., Arora, V. K., Jones, C. D., Anav, A., Liddicoat, S. K., \&Knutti, R. 2014. Uncertainties in CMIP5 climate projections due to carbon cycle feedbacks. J.Climate, 27, 511-526. Dio.10.1175/JCLI-D-12-00579.1

Gebrechorkos, S. H., Hülsmann, S., Bernhofer, C., 2018. Evaluation of Multiple Climate Data Sources for Managing Environmental Resources in East Africa. Hydro. Earth Syst. Sci., 22, 


\section{7-4564. https://doi.org/10.5194/hess-2017-558}

Gebrechorkos, S.H., Hülsmann, S., Bernhofer, C., 2019. Changes in temperature and precipitation extremes in Ethiopia, Kenya, and Tanzania. Int J Climatol 39:18-30. Dio: 10.1002/joc.5777

Gebremeskel, G., Tang, Q., Sun, S., Huang, Z., Zhang, X., Liu, X., 2019. Droughts in East Africa: Causes, impacts and resilience. Earth-Sci Rev, 193, 146-161. https://doi.org/10.1016/j.earscirev.2019.04.015

Gleckler, P. J., Taylor, K. E., \& Doutriaux, C. (2008). Performance metrics for climate models. J. Geophys. Res. 113. D06104, dio.10.1029/2007JD008972

Gusain, A., Ghosh, S., Karmakar, S. (2020). Added value of CMIP6 over CMIP5 models in simulating Indian summer monsoon rainfall. Atmospheric Research, 232, 104680.

Grose, M. R., Narsey, S., Delage, F. P., Dowdy, A. J., Bador, M., Boschat, G., Lyu, K. 2020. Insights from CMIP6 for Australia's future climate. Earth's Future, 8, e2019EF001469.

Haile, G.G., Tang, Q., Hosseini-Moghari, S.M., Liu, X., Gebremicael, T.G., Leng, G., Kebde, A., Yun, X. Projected impacts of climate change on drought patterns over East Africa. Earth's Future, https://doi.org/10.11029/2020EF001502

Hajima, T., Watanabe, M., Yamamoto, A., Tatebe, H., Noguchi, M. A., Abe, M., Ito, A. (2020). Development of the MIROC-ES2L Earth system model and the evaluation of biogeochemical processes and feedbacks. Geosci. Model Dev., 13(5), 2197-2244. Dio.org/10.5194/gmd-132197-2020

Hourdin F, Jam A, Rio C, et al. Unified parameterization of convective boundary layer transport and clouds with the thermal plume model. J Adv Mod Ear Syst 2019; 11: 2910-2933

IPCC, 2014. Climate Change 2014: Synthesis Report. Contribution of Working Groups I, II and III to the Fifth Assessment Report of the Intergovernmental Panel on Climate Change [Pachauri RK, Meyer LA (eds.)]. IPCC, Geneva, Switzerland, 151 pp.

IPCC., 2018. Global Warming of $1.5^{\circ} \mathrm{C}$ : An IPCC Special Report on the Impacts of Global Warming of $1.5^{\circ} \mathrm{C}$ Above Pre-Industrial Levels and Related Global Greenhouse Gas Emission Pathways, in the Context of Strengthening the Global Response to the Threat of Climate Change, Sustainable Development, and Efforts to Eradicate Poverty. Intergovernmental Panel on Climate Change.

Indeje, M., Semazzi, F.H.M., 2000. Relationships between QBO in the Lower Equatorial Stratospheric Zonal Winds and East African Seasonal Rainfall. Meteorol. Atmos. Phys. 73, 227-244. https://doi.org/10.1007/s007030050075.

Jiang, D., Hu, D., Tian, Z., Lang, X. 2020. Differences between CMIP6 and CMIP5 Models in Simulating Climate over China and the East Asian Monsoon. Adv. Atmos. Sci, 37, 11021118.https://doi.org/10.1007/s00376-020-2034-y

Juma, B., Olang, L. O., Hassan, M., Chasia, S., Bukachi, V., Shiundu, P., Mulligan, J. 2020. Analysis of rainfall extremes in the Ngong River Basin of Kenya: Towards integrated urban flood risk management. Phys. Chem. Earth, https: dio.org/10.1016/j.pce.2020.102929 
Kent, C, Chadwick, R, Rowell, D.P., 2015. Understanding uncertainties infuture projections of seasonal tropical precipitation. J Climate 28(11):4390-4413. https://doi.org/10.1175/JCLI-D14-00613.1

Kilavi, M., MacLeod, D., Ambani, M., Robbins, J., Dankers, R., Graham, R., Helen, T., Salih, A. A. M., Todd, M.C., 2018. Extreme rainfall and flooding over Central Kenya Including Nairobi City during the long-rains season 2018: causes, predictability, and potential for early warning and actions Atmosphere 9, 472. Dio. 10.3390/atmos9120472

Kisembe, J., Favre, A., Dosio, A., Lennard, L., Sabiiti, G., Nimusiima, A., 2018. Evaluation of rainfall simulations over Uganda in CORDEX regional climate models. Theor. Appl. Climatol. 137(1-2), 1117-1134.https://doi.org/10.1007/s00704-018-2643-X

Kimani, M.W., Hoedjes, J.C. B., Su, Z., 2017. An assessment of satellite-derived rainfall products relative to ground observations over East Africa. Remote Sens, 9. 430. https://doi.org/10.3390/rs9050430

Kim, Y. H., Min, S. K., Zhang, X., Sillmann, J., Sandstad, M. 2020. Evaluation of the CMIP6 multi-model ensemble for climate extreme indices. Weather and Climate Extremes, 29, 100269. https://dio.org/10.1016/j.wace.2020.100269

Kizza, M., Rodhe, A., Xu, C. Y., Ntale, H. K., Halldin, S., 2009. Temporal rainfall variability in the Lake Victoria Basin in East Africa during the twentieth century. TheorAppl Climatol., 98(1-2), 119-135. https://doi.org/10.1007/s00704-008-0093-6

Klein Tank, A.M.G., Zwiers, F.W., Zhang, X., 2009. Guidelines on analysis of extremes in a changing climate in support of informed decisions for adaptation. In: Climate Data and Monitoring WCDMP-No. 72, vol. 1500. WMO-TD No., p. 56

Krasting, J.P et al., 2018. NOAA-GFDL GFDL-ESM4 model output prepared for CMIP6 CMIP historical

Lamarque, J. F., Shindell, D. T., Josse, B., Young, P., Cionni, I., Eyring, V., Dalsoren, S. B. 2013. The Atmospheric Chemistry and Climate Model Intercomparison Project (ACCMIP): Overview and description of models, simulations and climate diagnostics. Geosci. Model Dev, 6, 179-206. Dio.10.5194/gmd-6-179-2013

Liebmann, B., Hoerling, M.P., Funk, C., Bladé, I., Dole, R.M., Allured, D., Quan, X., Pegion, P., Eischeid, J.K., 2014. Understanding Recent Eastern Horn of Africa Rainfall Variability and Change. J. Climate,27: 8630-8645. doi:10.1175/JCLI-D-13-00714.1

Lyon, B., Dewitt, D.G., 2012. A recent and abrupt decline in the East African long rains. Geophys. Res. Lett.,39, L02702. https://doi:10.1029/2011GL050337

Lyon, B., 2014. Seasonal drought in the Greater Horn of Africa and its recent increase during the March-May long rains. J. Clim. 27 (21), 7953-7975.

Luo, N., Guo, Y.,Gao, Z., Chen, K., Chou, J., 2020. Assessment of CMIP6 and CMIP5 model performance for extreme temperature in China,Atmospheric and Oceanic Science Letters, DOI: $10.1080 / 16742834.2020 .1808430$ 
Madakumbura, G. D., Kim, H., Utsumi, N., Shiogama, H., Fischer, E. M., Seland, Ø., Oki, T. 2019. Event-to-event intensification of the hydrologic cycle from $1.5^{\circ} \mathrm{C}$ to a $2^{\circ} \mathrm{C}$ warmer world. Sci Rep, 9. 3483. Dio.10.1038/s41598-019-39936-2

Mauritsen T, Bader J, Becker T, et al. Developments in the MPI-M Earth System Model version 1.2 (MPI-ESM1.2) and its response to increasing $\mathrm{CO}_{2}$. J Adv Mod Ear Syst 2019; 11: 9981038.https//dio.org/10.1029/2018MS001400

Moseid, K. O., Schulz, M., Storelvmo, T., Julsrud, I. R., Olivié, D., Nabat, P., Takemura, T. 2020. Bias in CMIP6 models compared to observed regional dimming and brightening trends (19612014). Atmospheric Chem. Phys.https://dio.org/10.5194/acp-2019-1210

Meehl, G. A., Boer, G. J., Covey, C., Latif, MStouffer, R. J. 1997. Intercomparison makes for a better climate model. Eos, Trans. AGU. 78, 445-451. Dio.10.1029/97EO00276

Meehl, G. A., Covey, C., McAvaney, B., Latif, M., Stouffer, R. J. 2005. Overview of the coupled model intercomparison project. Bull Amer. Meteor. Soc. 86, 89-93.Dio. 10.1175/BAMS-861-89

Meehl, G. A., C. Covey, T. Delworth, M. Latif, B. McAvaney, J.F. B. Mitchell, R. J. Stouffer, and K. E. Taylor, 2007: TheWCRP CMIP3 multimodel dataset: A new era in climatechange research. Bull. Amer. Meteorol. Soc., 88,1383-1394, https://doi.org/10.1175/BAMS-88-9$\underline{1383}$

Meehl, G. A., Goddard, L., Murphy, J., Stouffer, R. J., Boer, G., Danabasoglu, G.,Hegerl, G. 2009. Decadal prediction: Can it be skillful? Bull. Amer. Meteor. Soc, 90(10), 14671486.dio.10.1175/2009BASS2778.1

Mchugh, M.J., 2004. Near-Surface Zonal Flow and East African Precipitation Receipt during Austral Summer. J. Clim. 17, 4070-4079. https://doi.org/10.1175/15200442(2004)017<4070:NZFAEA>2.0.CO;2

Mumo, L., Yu, J., Fang, K., 2018. Assessing Impacts of Seasonal Climate Variability on Maize Yield in Kenya. Int. J. Plant Prod, 1-13. https://doi.org/10.1007/s42106-018-0027-x

Mumo, L., Yu, J.,2020. Gauging the performance of CMIP5 historical simulation in reproducing observed gauge rainfall over Kenya. Atmos Res. 236 (2020): 104808 https://doi.org/10.1016/j.atmosres.2019.104808

Mutai, C.D., Polzin, and Hastenrath, S., 2012. Diagnosing Kenya rainfall in boreal autumn: Further exploration, J. Clim., 25(12), 4323-4329, doi:10.1175/JCLI-D-11-00414.1.

Niang, I., Ruppel, O.C., Abdrabo, M.A., Essel, A., Lennard, C., Padgham, J., Urquhart, P., 2014. Africa. In: Climate Change 2014: Impacts, Adaptation, and Vulnerability. Part B: Regional Aspects. Contribution of Working Group II to the Fifth Assessment Report of the Intergovernmental Panel on Climate Change [Barros VR, Field CB, Dokken DJ, Mastrandrea MD, Mach KJ, Bilir TE, Chatterjee M, Ebi KL, Estrada YO, Genova RC, Girma B, Kissel ES, Levy AN, MacCracken S, Mastrandrea PR, White LL (eds.)]. Cambridge University Press, Cambridge, United Kingdom and New York, NY, USA, 1199-1265 pp.

Nie, Y., L. J. Li, Y. L. Tang, and B. Wang, 2019: Impacts ofchanges of external forcings from CMIP5 to CMIP6 on surface temperature in FGOALS-g2. Sola, 15, 211- 
215,https://doi.org/10.2151/sola.2019-038.

Nikulin, G., Jones, C., Giorgi, F., Asrar, G., Büchner, M., Cerezo-Mota, R., Christensen, O.B, Déqué, M., Fernandez, J., Hänsler, A., van Meijgaard, E., 2012. Precipitation climatology in an ensemble of CORDEX-Africa regional climate simulations. J.Climate 25 (18), 6057-6078. https://dio.org/10.1175/JCLI-D-11-00375.1

Nicholson, S.E., 2014. A detailed look at the recent drought situation in the Greater Horn of Africa. J. Arid Environ. 103, 71-79. https://doi.org/10.1016/jaridenv.2013.12.003

Nicholson, S.E., 2015, Long-term variability of the East African "short rains" and its links to largescale factors, Int. J. Climatol., 35(13), 3979-3990, doi:10.1002/joc.4259.

Nicholson, S.E., 2018. The ITCZ and the Seasonal Cycle over Equatorial Africa. Bull. Amer. Meteor. Soc. 99 (2): 337-348. https://doi.org/10.1175/BAMS-D-16-0287.1

Ngoma, H., Wen, W., Ayugi, B., Babaousmail, H., Karim, R., Ongoma, V., 2021. Evaluation of the Global Climate Models in CMIP6 in simulating mean precipitation over Uganda. Int. J. Climatol. Under press

Ogega, O.M., Koske, J., Kung'u, J.B., Scoccimarro, E., Endris, H.S., Mistry, M., 2020. Heavy precipitation events over East Africa in a changing climate: results from CORDEX RCMs. Clim. Dyn. 2020. doi.org/10.1007/s00382-020-05309-z.

Ogwang, B.A, Chen, H., Li, X., Gao, C., 2014. The Influence of Topography on East African October to December Climate: Sensitivity Experiments with RegCM4. Adv. Meteorol. 2014. ID 143917. https://doi.org/10.1155/2014/143917

Ongoma, V., Chen, H., 2017. Temporal and spatial variability of temperature and precipitation over East Africa from 1951 to 2010. Meteorol. Atmos. Phys. 129(2) 131144.https://doi.org/10.1007/s00703-016-0462-0

Ongoma, V., Chen, H., Gao, C., 2018a. Projected Change in Mean Rainfall and Temperature over East Africa based on CMIP5 Models. Int. J. Climatol. 38: 1375-1392 https://doi.org/10.1002/joc.5252

Ongoma, V., Chen, H., Gao, C., Nyongesa, A.M., Polong, F., 2018b.Future changes in Climate Extreme over Equatorial East Africa based on CMIP5 multimodel ensemble. Nat Haz, 90, 901-920.doi.org/10.1007/s11069-017-3079-9

Onyutha, C., 2020. Analyses of rainfall extremes in East Africa based on observations from rain gauges and climate change simulations by CORDEX RCMs. ClimDyn (2020). https://doi.org/10.1007/s00382-020-05264-9

Osima, S., Indasi, V.S., Zaroug, M., Endris, H.S., Gudoshava, M., Misiani, H.O., Dosio, A., 2018. Projected Climate over Greater Horn of Africa under $1.5^{\circ} \mathrm{C}$ and $2^{\circ} \mathrm{C}$ global warming. Environ. Res. Lett.13, 6. https://doi.org/10.1128/JVI.74.13.6223-6226.2000

Otieno, V.O., Anyah, R.O. 2013a. CMIP5 simulated climate conditions of the Greater Horn of Africa (GHA). Part 1: Contemporary climate. Clim. Dyn.,41: 2081-2097. doi:10.1007/s00382-012-1549-z 
Otieno, V.O., Anyah, R.O. 2013b. CMIP5 simulated climate conditions of the Greater Horn of Africa (GHA). Part II: Projected climate. Clim. Dyn.,41: 2099-2113. doi:10.1007/s00382013-1694-Z

Philippon, N., Camberlin, P., Fauchereau, N.2002. Empirical predictability study of OctoberDecember east African rainfall. Q.J.R: Meteorol.Soc, 128(585), 2239-2256. doi: 10.1256/qj.01.190

Seneviratne, S.I., Nicholls, N., Easterling, D., Goodess, C.M., Kanae, S., Kossin, J., Luo, Y., Marengo, J., McInnes, K., Rahimi, M., Reichstein, M., Sorteberg, A., Vera, C., Zhang, X 2012. Changes in climate extremes and their impacts on the natural physical environment. In: Managing the Risks of Extreme Events and Disasters to Advance Climate Change Adaptation. A Special Report of Working Groups I and II of the Intergovernmental Panel on Climate Change [Field CB, Barros V, Stocker TF, Qin D, Dokken DJ, Ebi KL, Mastrandrea MD, Mach KJ, Plattner G-K, Allen SK, Tignor M, Midgley PM (eds.)]. Cambridge University Press, Cambridge, UK and New York, NY, USA, pp. 109 -230.

Seneviratne, S. I., and Hauser, M. 2020. Regional Climate Sensitivity of Climate Extremes in CMIP6 Versus CMIP5 Multimodel Ensembles. Earth's future, 8, e2019EF001474.

Seland $\varnothing$, Bentsen M, Graff LS, et al. The Norwegian Earth System Model, NorESM2-Evaluation of the CMIP6 DECK and historical simulations. Geosci Model Dev Diss 2020; https://doi.org/10.5194/gmd-2019-378

Sillmann, J.V., Kharin, V., Zhang, X.W., Zwiers, F., Bronaugh, D., 2013. Climate extremes indices in the CMIP5 multimodel ensemble: Part 2. Future climate projections. J. Geophys. Res., 118: 2473-2493. doi:10.1002/jgrd.50188.

Shongwe, M.E, Van Oldenborgh, G.J, Van den Hurk, B, Van Aalst M., 2011. Projected changes in mean and extreme precipitation in Africa under global warming. Part II: East Africa. J Climate 24: 3718-3733. http://doi.org/10.1175/2010JCLI2883.1.

Smith, D. M., Scaife, A. A., Boer, G. J., Caian, M., Doblas-Reyes, F. J., Guemas, V., Ishii, M. 2013. Real-time multi-model decadal climate predictions. ClimDyn, 41, 2875-2888. Dio.10.1007//s00382-012-1600-0

Stouffer, R. J., Eyring, V., Meehl, G. A., Bony, S., Senior, C., Stevens, B., Taylor, K. E. 2017. CMIP5 scientific gaps and recommendations for CMIP6. Bull. Amer. Meteor. Soc. 98, 95105. Dio.1175/BAMS-D-15-00013.1

Su, F., Hong, Y., Lettenmaier, D.P., 2008. Evaluation of TRMM Multisatellite Precipitation Analysis (TMPA) and Its Utility in Hydrologic Prediction in the La Plata Basin. J. Hydometeor, 9(4), 622-640. doi.org/10.1175/2007JHM944.1.

Swart, N.C., et al., 2019. The Canadian Earth System Model version 5 (CanESM5.0.3) Geosci Model Dev 2019; 12: 4823-4873

Riahi, K., Rao, S., Krey, V., Chom C., Chirkov, V., Fischer, G., Kindermann, G., Nakicenovic, N., Rafaj, P. 2011. RCP 8.5-A scenario of comparatively high greenhouse gas emissions. Clim. Chang., 109: 33-57. doi:10.1007/s10584-011-0149-y 
Rowell, D.P., Booth, B.B.B., Nicholson, S.E., Good, P., 2015. Reconciling past and future rainfall trends over East Africa. J. Clim. 28 (24), 9768-9788. https://doi.org/10.1175/JCLI-D-150140.1

Tan, G., Ayugi, B., Ngoma, H.N., Ongoma, V., 2020. Projections of Future Meteorological Drought Events under representative concentrations pathways (RCPs) of CMIP5 over Kenya, East Africa. Atmos Res. https://doi.org/10.1016/j.atmosres.2020.105112

Tatebe H, Ogura T, Nitta T, et al. Description and basic evaluation of simulated mean state, internal variability, and climate sensitivity in MIROC6. Geosci Model Dev 2019; 12: 2727-2765

Taylor, K.E., 2001. Summarizing multiple aspects of model perfomance in a Single Diagram. J. Geophys. Res, 106(D7), 7183-7192. https://doi.org/10.1029/2000JD900719.

Taylor, K. E., Stouffer, R. J., Meehl, G.A., 2012. An overview of CMIP5 and the experiment design. Bull Am Meteorol Soc, 93, 485-498. Dio. 10.1175/BAMS-D-11-00094.1

van Vuuren DP, Den Elzen MGJ, Lucas PL, Eickhout B, Strengers BJ, Van Ruijven B, Wonink S, Van Houdt R (2007) Stabilizing greenhouse gas concentrations at low levels: an assessment of reduction strategies and costs. Clim. Chang., 81:119-159. doi:10.1007/s 10584-006-91729

Voldoire, A., Saint-Martin, D., Sénési, S., Decharme, B., Alias, A., Chevallier, M., Colin, J., Guérémy, J. F., Michou, M., Moine, M. P., Nabat, P., Roehrig, R., Salas y Mélia, D., Séférian, R., Valcke, S., Beau, I., Belamari, S., Berthet, S., Cassou, C., Cattiaux, J., Deshayes, J., Douville, H., Ethé, C., Franchistéguy, L., Geoffroy, O., Lévy, C., Madec, G., Meurdesoif, Y., Msadek, R., Ribes, A., Sanchez-Gomez, E., Terray, L., \& Waldman, R. (2019). Evaluation of CMIP6 DECK experiments with CNRM-CM6-1. J Adv Model Earth Syst., 11, 2177-2213. Dio.org/10.1029/2019MS001683

Volodin EM, Mortikov EV, Kostrykin SV, et al. Simulation of the present-day climate with the climate model INMCM5. ClimDyn 2017; 49 3715-3734

Wang, B., Zheng, L., Liu, D. L., Ji, F., Clark, A., Yu, Q. 2018. Using multi-model ensembles of CMIP5 global climate models to reproduce observed monthly rainfall and temperature with machine learning methods in Australia. Int J Climatol.38(13), 4891-4902.Dio: 10.1002/joc.5705

Williams, A.P., Funk, C., 2011. A westward extension of the warm pool leads to a westward extension of the Walker circulation, drying eastern Africa. Clim. Dyn.,37,2417-2435. https://doi:10.1007/s00382-010-0984-y

Wieners, Karl-Hermann; Giorgetta, Marco; Jungclaus, Johann; Reick, Christian; Esch, Monika; Bittner, Matthias; Gayler, Veronika; Haak, Helmuth; de Vrese, Philipp; Raddatz, Thomas; Mauritsen, Thorsten; von Storch, Jin-Song; Behrens, Jörg; Brovkin, Victor; Claussen, Martin; Crueger, Traute; Fast, Irina; Fiedler, Stephanie; Hagemann, Stefan; Hohenegger, Cathy; Jahns, Thomas; Kloster, Silvia; Kinne, Stefan; Lasslop, Gitta; Kornblueh, Luis; Marotzke, Jochem; Matei, Daniela; Meraner, Katharina; Mikolajewicz, Uwe; Modali, Kameswarrao; Müller, Wolfgang; Nabel, Julia; Notz, Dirk; Peters, Karsten; Pincus, Robert; Pohlmann, 
Holger; Pongratz, Julia; Rast, Sebastian; Schmidt, Hauke; Schnur, Reiner; Schulzweida, Uwe; Six, Katharina; Stevens, Bjorn; Voigt, Aiko; Roeckner, Erich (2019). MPI-M MPI-ESM1.2LR model output prepared for CMIP6 ScenarioMIP ssp245. Version YYYYMMDD ${ }^{[1]}$.Earth System Grid Federation. https://doi.org/10.22033/ESGF/CMIP6.6693

World Bank, 2012. Doing business in the East African economies.IFC/World Bank Rep., 116 Wu, T., Chu, W., Dong, M., Fang, Y., Jie, W., Li J., Li, W., Liu, Q., Shi, X., Xin, X., Yan, J., Zhang, F., Zhang, J., Zhang, L., Zhang, Y., 2019. BCC BCC-CSM2MR model output prepared for CMIP6 CMIP historical Earth System Grid Federation. https://doi.org/10.22033/ESGF/CMIP6.2948.

Xin, X., Wu, T., Zhang, J., Yao, J., Fang, Y., 2020. Comparison of CMIP6 and CMIP5simulations of precipitation in China and the EastAsian summer monsoon. Int J Climatol. 2020;118.https://doi.org/10.1002/joc.6590

Yang, W., Seager, R., Cane, M.A., Lyon, B., 2015. The annual cycle of East African precipitation. J. Climate, 28(6), 2385-2404. doi.org/10.1175/JCLI-D-14-00484.1

Yukimoto, Seiji; Koshiro, Tsuyoshi; Kawai, Hideaki; Oshima, Naga; Yoshida, Kohei; Urakawa, Shogo; Tsujino, Hiroyuki; Deushi, Makoto; Tanaka, Taichu; Hosaka, Masahiro; Yoshimura, Hiromasa; Shindo, Eiki; Mizuta, Ryo; Ishii, Masayoshi; Obata, Atsushi; Adachi, Yukimasa (2019). MRI MRI-ESM2.0 model output prepared for CMIP6 CMIP. Version YYYYMMDD.Earth System

Grid Federation. https://doi.org/10.22033/ESGF/CMIP6.621

Zamani, Y., Monfared, S. A. H., Hamidianpour, M. 2020. A comparison of CMIP6 and CMIP5 projections for precipitation to observational data: the case of Northeastern Iran. Theor Appl Climatol. 142, 1613-1623.https://dio.org/10.1007/s00704-020-03406-x.

Ziehn, Tilo; Chamberlain, Matthew; Lenton, Andrew; Law, Rachel; Bodman, Roger; Dix, Martin; Wang, Yingping; Dobrohotoff, Peter; Srbinovsky, Jhan; Stevens, Lauren; Vohralik, Peter; Mackallah, Chloe; Sullivan, Arnold; O'Farrell, Siobhan; Druken, Kelsey (2019). CSIRO ACCESS-ESM1.5 model output prepared for CMIP6 CMIP. Version YYYYMMDD. Earth System Grid Federation. https://doi.org/10.22033/ESGF/CMIP6.2288

Zhang, X., Alexander, L., Hegerl, G.C., Jones, P., Klein Tank, A., Peterson, T.C., Trewin, B., Zwiers, F.W., 2011. Indices for monitoring changes in extremes based on daily temperature and precipitation data. WIREs Clim. Chang. 2, 851-870. Dio. 10.1002/wcc.147

Zhu, H.H., Jiang, Z.H., LI, J., Li, W., Sun, C.X., Li, L.,2020. Does CMIP6 inspire more confidence in simulating climate extremes over China? Adv. Atmos. Sci., 37, 1119-1132, https://doi.org/10.1007/s00376-020-9289-1. 
Zhu, Y. Y., Yang, S.2020. Evaluation of CMIP6 for historical temperature and precipitation over the Tibetan Plateau and its comparison with CMIP5. Adv. Clim. Change Res. https://dio.org/10.1016/j.accre.2020.08.001 